\title{
Indicators and tools for assessing sustainability impacts of the forest bioeconomy
}

\author{
Jaakko Karvonen ${ }^{*}$, Pradipta Halder ${ }^{2}$, Jyrki Kangas ${ }^{2}$ and Pekka Leskinen ${ }^{1}$
}

\begin{abstract}
The sustainable use of renewable resources has become an important issue worldwide in the move towards a less fossil-fuel-intensive future. Mainstream method for fulfilling this aim is to increase the share of renewable energy and materials to substitute fossil fuels and to become fully independent from fossil fuels over the long-term. However, the environmental sustainability of this endeavor has been questioned. In addition, economic and social sustainability issues are also much debated topics in this particular context. Forest resources are often thought to contribute partially to achieving a so-called "carbon-neutral society". In this review, we discuss sustainability issues of using forest biomass. We present several sustainability indicators for ecological, economic and social dimensions and discuss the issues in applying them in sustainability impact assessments (SIAs). We also present a number of tools and methods previously used in conducting SIAs. We approach our study from the perspective of the Finnish forestry; in addition, various aspects regarding the application of SIAs in a broader context are also presented. One of the key conclusions of the study is that although sufficient data are available to measure many indicators accurately, the impacts may be very difficult to assess (e.g. impact of greenhouse gases on biodiversity) for conducting a holistic SIA. Furthermore, some indicators, such as "biodiversity", are difficult to quantify in the first place. Therefore, a mix of different methods, such as Multi-criteria Assessment, Life-cycle Assessment or Cost-Benefit Analysis, as well as different approaches (e.g. thresholds and strong/weak sustainability) are needed in aggregating the results of the impacts. SIAs are important in supporting and improving the acceptability of decision-making, but a certain degree of uncertainty will always have to be tolerated.
\end{abstract}

Highlights: · Forest bioeconomy involves a range of multidimensional impacts.

- A variety of methods exist to assess and evaluate sustainability.

- Social sustainability is the most case-specific dimension to assess.

- Indicators used in SIAs need case-specific considerations.

-More consistency is needed regarding the concept and terminology of sustainability.

Keywords: Forest bioeconomy, Sustainability, Indicators, Impact assessment, Decision support

\section{Introduction}

Climate change is one of the most significant threats facing the world today, and mitigation of it has been recognized as an issue requiring urgent and extensive actions on the part of the global community. At the Paris Climate Conference in December 2015, 195 countries adopted the first-ever universal, legally binding global climate agreement. They agreed to take global measures in order to "put the world on track" and to

\footnotetext{
* Correspondence: jaakko.karvonen@ymparisto.fi

${ }^{1}$ Finnish Environment Institute, Yliopistokatu 7, 80100 Joensuu, Finland Full list of author information is available at the end of the article
}

avoid dangerous effects of the climate change by limiting global warming to well below $2{ }^{\circ} \mathrm{C}$. Among the proposed measures, an important issue is to transform our current fossil fuel-based energy generation systems to a sustainable and renewable energy (RE)-based systems by using so-called 'carbon-neutral' alternatives.

According to the IEA (2015), more than $80 \%$ of the global energy demand is met by fossil fuels, while the current supply of RE is insufficient to meet that demand. At the same time, there are widespread concerns over the depletion of fossil fuel reserves and thus new sources are being explored (Cieślak and Gaj 2014). It is necessary 
to increase the supply of energy produced from various RE sources in order to avoid an energy-scarce world due to the fast depletion of fossil fuels. Biomass is one of the RE options. Currently, using biomass alone is not sufficient to substitute all the fossil energy. Planetary boundaries for food, biodiversity, clean water and fresh air have also become matters of serious concern (Helin et al. 2014; Mancini et al. 2015). Via land-use and land-use change biomass production for materials and energy may compete over planetary boundaries with food production and perhaps negatively impact biodiversity and the availability of clean water and fresh air. Hence, it is important to make certain that RE and materials made of biomass will not become a threat for example to food and water availability.

Forests are expected to play an important role in moving towards a fossil fuel-free and low-carbon society, especially in countries rich in forests (Helin et al. 2014). Wood is a renewable biomass, which has a special status in comparison to other types of RE because it is easier to store, can be used as such or converted it into solid, liquid and gaseous products (Akhtari et al. 2014; Moriana et al. 2015). In addition, wood is used in construction and for producing pulp and paper and manufacturing furniture. It can also be converted into a range of other goods with a variety of uses such as hydrogels, reinforcement polymers and resorcinolformaldehyde (Moriana et al. 2015). All these may substitute fossil resources in the future and thus science is searching for new methods to improve the efficiency of using wood for various purposes (Silveira et al. 2015).

\section{Review}

Our review aims to explore the most important and relevant sustainability indicators and impact assessment methods to support decision-making in a forest-based bioeconomy. A forest bioeconomy is understood as an activity utilizing wood and other non-wood products (e.g., berries and mushrooms) obtained from forests or side streams of forest biomass from other industrial activities. Forest bioeconomy also includes forestry related operations such as harvesting, transporting and refining of forest biomass. Sustainability is considered by us as a combination of environmental, economic and social conditions. We approached the topic from a Finnish perspective mainly for three reasons. In first instance the Finnish government is aiming for greater use of forests (Suomen biotalousstrategia 2014; Sipilä 2015) and forest industries have made significant investments in Finland some of which are under construction (e.g. Metsä Group 2015) and others are planned but not yet decided upon (Finnpulp 2015; Kaidi 2016). For example in Äänekoski a biofactory is under construction which alone is an investment worth about 1 billion euros, will increase annual wood use by 4.3 million $\mathrm{m}^{3}$, creates some 1500 new jobs into the value chain and is expected to contribute 500 million euros to national income (Metsä Group 2015). Its impacts are significantly positive on the economy and employment but its wood consumption will cause stresses on the forest ecology. Therefore, there is an urgent need for assessing the sustainability impacts of this development, especially if all the investments planned were to be realized. Secondly, forests have long been an essential part of the Finnish national economy representing over 20\% of its exports in 2013 (Official Statistics Finland 2014a, b). Finally, social, ecological and economic conditions change drastically around the globe and within a defined context we can discuss the sustainability indicators more in-depth.

To assess sustainability, multidimensional impact assessments for decision-making are needed (Kangas et al. 2015). Especially, there is a need for a methodology to conduct consistent, holistic, reliable and realistic life cycle sustainability impact assessments (LCSIA) about forest use in a framework considering economic, ecological and social dimensions (3D) to support decisionmaking and to develop policies. It is also important to provide tools to weigh prioritized viewpoints, attributes or aspects, as well as the dimensions of sustainability.

We expected that some indicators would be difficult to measure and indirect variables and models are needed to include some indicators in sustainability impact assessment (SIA) methods. We expected that some indicators would be strongly interlinked between dimensions and that one such indicator could provide inter-dimensional information. By identifying these types of "driver" indicators, it may be possible to simplify the assessment task. Lastly, we expected that with a rather small number of indicators it would be possible to conduct a SIA, capable of giving reliable, understandable and comprehensive results of sustainability of the forest-based bioeconomy in Finland.

The paper continues as follows. First, we introduce the concept of sustainability in the context of forestry and the three main dimensions of sustainability. After this, we discuss individual indicators of ecological, economic and social dimensions one by one. After presenting the indicators, we introduce several methods, which have been used in SIAs. Lastly, we discuss the findings of our investigation and the paper ends with our conclusions.

\section{Defining and assessing sustainability of forestry}

As early as the 21 st century $\mathrm{BC}$, China paid attention to sustainability in forest management. Since then it has been subject to many definitions and viewpoints (MacDicken et al. 2015). Sustainability in forestry used to focus on sustainable timber yield; however, more recently it has adopted a multidimensional approach (Tuomasjukka et al. 2013a). In such a multidimensional approach, social, ecological and economic dimensions 
(the 3Ds) are simultaneously considered. Some have also extended the concept to spiritual and cultural dimensions (MCPEF 1993; Leskinen et al. 2012). The Ministerial Conference on the Protection of Forests in Europe (MCPFE) has defined sustainable forest management in its Helsinki Resolution in 1993 as follows:

"The stewardship and use of forests and forest lands in a way, and at a rate, that maintains their biodiversity, productivity, regeneration capacity, vitality and their potential to fulfill, now and in the future, relevant ecological, economic and social functions, at local, national, and global levels, and that does not cause damage to other ecosystems." (MCPEF 1993).

The extended view over sustainability is probably due to the recognition of the limited and constantly diminishing, yet increasingly over-exploited natural resources causing ecological stress with detrimental impacts on the environment. Some researchers have concluded that the anthropogenic consumption has already reached the biophysical limits of the Earth (see Mancini et al. 2015). Therefore, assessing sustainability to ensure that Earth will be able to support its diverse life forms in the future has become critically important. Unsustainability may result from (over) emphasizing one dimension over the others (Klooster 2010; Villamagna et al. 2013; Kopnina 2016) and thus, considering the $3 \mathrm{D}$ approach becomes essential. Some recent studies on the forest-based bioeconomy and its multidimensional impacts can be found for example in Heink and Kowarik (2010), den Herder et al. (2012), Leskinen et al. (2012), Cambero and Sowlati (2014) and Jäppinen et al. (2014).

Utilization of forests may be perceived variously by different stakeholders making sustainability an ambiguous concept (Kangas et al. 2015). Aside from extreme considerations (e.g. from an environmental activist or utilitarian viewpoint), the overall impacts, value preferences and stakeholder engagement will, in general, affect the acceptance of using forests (Haatanen et al. 2014). However, this acceptance may not guarantee sustainability if, for example, general acceptance leads to the consideration of only short term benefits while neglecting long-term perspectives (Sverdrup et al. 2006). Therefore, it is important to establish objectives rationally as well as to provide science and knowledge-based initial assessments about sustainability in order to exclude unsustainable options from possible alternatives.

\section{The three main dimensions of sustainability}

The economic dimension of sustainability is perhaps the easiest one to comprehend because money as economic measure is commonly understood as "the more the better" (except for costs). Economists may try to quantify all values (from all dimensions) into a single measure; however, this may be impossible or undesirable in some cases (Hall 2015). Economics are embedded in SIA and are without a doubt, an important part of sustainability, for example, in efforts to optimize resource allocation (Hall 2015). Sometimes, a decision may be made solely for economic interests and goals; however, since Earth resources are limited, economic priorities should stay within the planetary boundaries (Janeiro and Patel 2015). Discounting is a common practice in economics although the relation between time and money has been argued as ethically problematic (Hall 2015) and is thus a questionable practice in SIAs.

Ecological or environmental sustainability refers to impacts and changes in the environment (e.g. biodiversity, land use, soil and water conditions) caused by anthropogenic activities (Villamagna et al. 2013). Ecological sustainability is connected to the concept of the ecosystem services (ES) which can be considered as the core of sustainability, referring to the capacity or quality of all that nature provides (e.g. air, water soil, wood and food) (Villamagna et al. 2013). Thus, the ES defines what resources are available on the planet. The ES approach provides a way to understand the trade-offs associated with the management of natural resources (Villamagna et al. 2013). Human-caused stress on Earth is already at an unsustainable level and therefore, we need to find more sustainable ways to use natural resources (Ernst 2012; Mancini et al. 2015).

Social sustainability has been studied less than economic or ecological sustainability (Acevedo Tirado et al. 2015). In addition, the social dimension is perhaps the least universally applicable and Acevedo Tirado et al. (2015) state that social sustainability is most meaningful when being assessed at regional or national levels. For example, income is hardly comparable in a global frame, given that an increase of one euro per week in salary has a different magnitude of impact depending on a referenced salary level. Poverty, malnutrition, inequality, as well as other social issues reach their extremes in developing countries (Acevedo Tirado et al. 2015), whereas such social problems seem to be rather insignificant in developed countries. However, support for universal social indicators is found in the review by Jørgensen et al. (2007) on social sustainability.

\section{Interlinked dimensions}

Classifying sustainability in individual dimensions is challenging, for many impacts are interlinked and overlapping. Multidimensional approaches allow us to examine how an impact on one dimension is reflected in other dimensions. For example, if we expect an increase in gross domestic product (GDP) (economic), we may expect impacts on well-being (social) as well as on the 
use of natural resources (ecological). Therefore, a multidimensional approach is essential for overall sustainability assessment. Sustainability has been approached from many angles, such as compensation, thresholds and strong or weak sustainability (see Ayres et al. 2001; De Mare et al. 2015; Janeiro and Patel 2015). The very concept of sustainability has also been criticized for its anthropocentricity (see Kopnina 2016). It is important to notice that the conditions in all the 3Ds do vary between locations - yet, some impacts have a global reach (i.e. global warming and trade). Thus, how sustainability is measured and evaluated is always a case-sensitive task and not least due to differing community, cultural or operational reasons.

\section{Data search}

Our search for indicators was conducted through database searches in the Web of Science. The keywords included sustainab ${ }^{*}$, forest $t^{*}$, indicat", social*, environment", ecolog ${ }^{*}$, econom $^{*}$ and biodiversity*. These keywords were used both independently and in combinations. During the search for impact assessment tools, keywords such as multi-criteria analysis (MCA) life cycle assessment (LCA), material flow analysis (MFA), sustainability impact assessment (SIA), environmental extended input-output (EEIO), input-output (IO), life cycle costing (LCC) and environmental life cycle costing (ELCC) were used. Sometimes, a search for indicators resulted in finding papers discussing SIA tools and vice versa. We also followed citations and references provided in the literature when it was considered meaningful. In addition, some legislative and statistical information were obtained directly from official administrative internet sites (e.g. Finlex Data Bank and Official Statistics Finland).

\section{Sustainability indicators of the forest bioeconomy Ecological indicators}

In forestry, ecological sustainability is affected by a number of factors which are either directly or consequentially related to others (Cambero and Sowlati 2014). We restricted our list to the following indicators presented below, which we considered the most important ones for maintaining the capacity and quality of those ecosystem services (ES) related to forestry. In practice, the Forest Act of Finland (Metsälaki 1996) defines the legal standards, which forest owners and operators have to take into consideration in forestry operations to ensure sustainability. For example, the Forest Act (Metsälaki 1996) includes several key habitats to be preserved. However, since sustainability is an ambiguous concept, we argue that the Act alone is not sufficient to ensure sustainability of Finnish forests. For example, active forest management and forest fire suppression have made forest fires rare in Finland, which have been shown to threaten fire-associated and saproxylic species (Kouki et al. 2012). Secondly, the range of the protected areas may not be enough to preserve the sites. Finally, increased wood use and changes in the type of wood in demand may change forest management schemes too (Cao et al. 2015a, b) causing other ecological impacts.

Greenhouse gases Perhaps among the most important ecological indicators of bioeconomy are the greenhouse gases (GHGs) or the aggregation of different GHGs under the term of global warming potential (GWP) (IPCC 2014; Levasseur et al. 2012). Developed countries have committed to the Kyoto Protocol to decrease their GHG emissions in 1998 (UNFCCC 1998). Since then, the European Union (EU) has set its own targets to mitigate climate change by decreasing GHG emissions (EU regulation No 525/2013; Decision No 406/2009/EC 2009). GHGs are perceived as threats due to their role in climate change (or global warming) and anthropogenic GHG emissions into the atmosphere as the main cause of it (IPCC 2014). The consequences of extreme weather events, rising sea levels and loss of biodiversity may have severe consequences to both humans and nature.

GHG is an indicator, which is relatively easy to measure, to some extent even accurately. In forestry, major non-renewable GHG emissions are due to the use of fossil fuels during extraction, transporting and processing of raw materials, product delivery, utilization and disposal (Cambero and Sowlati 2014). Once the (fossil) inputs are known (e.g. in energy plants), the total GHG calculation is a relatively simple mathematical task. More difficult would be to estimate indirect GHG emissions, such as emissions from soils due to changes in soil activity (Levasseur et al. 2012).

The debate continues over whether carbon emissions from renewable origins should, as is common, be considered 'carbon neutral' and in which time frame (McKechnie et al. 2011; Czeskleba-dupont 2012) or should some other approaches be considered (Pawelzik et al. 2013). In the carbon-neutral approach the GHG (or carbon) emissions emitted from biomass combustion are omitted in GHG calculations because they are assumed to be bound by (re)growing vegetation forming a carbon neutral circle where the total amount of GHG in the atmospheric cycle is not increasing. However, acquisition of biomass does include fossil inputs (e.g. fuels) and the impact of the GHG emissions from combustion of biomass and fossil fuels are, in principal, the same in respect to their climate impacts. Therefore, the total of the immediate GHG emissions may be higher for biomass than for fossil fuels per unit of energy produced. In a short time frame this may be problematic, considering the underlying climate change mitigation goals. Nevertheless, biomass itself does not increase the total amount 
of carbon in the atmospheric cycle and hence in the long run all the fossil fuels substituted by biomass results in less carbon in the atmosphere and therefore mitigates global warming.

International efforts for GHG mitigation are already agreed upon, the Paris 2015 Agreement being the latest among them. The GHG-indicator contributes to the general aim towards climate neutrality. In addition, GHG is a global sustainability indicator and interlinked with many factors, such as fossil fuel use. Much of the data needed to calculate the emissions of GHGs is derivable from national statistics. All the same, further precision for allocation is still possible with operational level data (e.g. fuel consumption in processes) and in the absence of such data we have to rely on estimates (e.g. carbon sink and substitution). The GHG value may be given in absolute terms, or in a more illustrative manner, such as the carbon footprint (Mancini et al. 2015). However, assessing the impacts of the GHGs with certainty is far from precise and more research is needed on that part. Moreover, some skepticism among people persists concerning climate change, its causes and impacts.

Fossil fuel use Fossil fuel use is a well-suited indicator for supporting decision-making from many perspectives, given that it is understandable, accountable and linked to many dimensions of sustainability (see Pawelzik et al. 2013). For example, substitution of fossil fuels with forest-based alternatives can provide much information about GHGs and the economy (den Herder et al. 2012) and presented in both absolute terms (volume and monetary value) and in relative numbers, such as shares in national consumption or trade. Limiting fossil fuel use is an effective way to mitigate climate change. In addition, utilization and extraction of fossil resources increases the number of environmental hazards, such as oil spills, more than producing renewable fuels do (Ernst 2012).

Fossil fuel use could be used as an indicator incorporated in GHG; however, due to the central role of fossil fuels in many other aspects of sustainability, it is more informative if measured separately. In Finland data about fossil fuel use are readily available from the Official Statistics of Finland (2016a). For reasons of GHG calculation and price fluctuation, volumetric values may be prioritized even though monetary values are also very informative. More detailed information is still needed for calculating the rates of substitution for using wood instead of its fossil counterparts in its various uses, especially considering recycling and cascade uses, not to mention any new innovations.

Fine particle emissions Fine particle emissions have adverse health effects. The National Institute for Health and Welfare (THL) in Finland estimates that exposure to fine particles causes more environment-related harm on health than all the other environmental factors combined (THL 2016).

Fine particles (particles less than 10 micrometers $(\mu \mathrm{m})$ in diameter) in the air arise from a number of sources such as from wood and oil combustion, forest fires and traffic (Ohlström et al. 2000; Lamberg et al. 2011; Ferranti 2014). Forms and formation of fine particles in the air vary in size, chemical composition and by their behavior in the atmosphere (Ohlström et al. 2000). Their physiochemical attributes and toxicological risks were found to differ significantly depending on the fuel and the combustion technology (Ohlström et al. 2000; Lamberg et al. 2011). A number of variables and attributes such as combustion process conditions and practices, as well as the quality of the raw material used affect the composition of emissions released (Ohlström et al. 2005).

A recent report by THL (2014a) shows that there is no 'safe level' of fine particle emissions and argues that 'safe-levels' are more of a political statement than that of a scientifically proven fact. The quantities of fine particles in the air are measurable in absolute terms and we should apply a precautionary approach and prefer minimizing particle emissions while waiting for more accurate studies about their impacts. Due to legislated regulations (e.g. EU directive 2015/2193; Finnish laws $750 / 2013$ and 936/2014), fine particle emissions data are readily available in many cases.

Water contamination Possible contamination or declining quality of water sources are of global concern and should not be neglected (Pawelzik et al. 2013). Water contamination may have impacts on health, recreation and biodiversity. However, water protection measures (water treatment) may bring on economic burdens.

In Finland, ground water and water in lakes and streams is abundant and much attention is devoted to protect these water sources. Eutrophication is one major threat to surface waters and the main pollutants causing it are phosphorus and nitrogen. The actual impacts of the pollutants ending up in water courses may be assessed in a number of ways (Pawelzik et al. 2013; Tattari et al. 2015). Water pollution from Finnish forests is largely the result from runoffs after final cuttings, ditching (mostly maintenance) and fertilizations (Tattari et al. 2015). Many uncertainties are involved in their measurements, leading to questions about their accuracy, although several studies have provided some valid data and their actual impacts may be calculated in a number of ways (Pawelzik et al. 2013; Tattari et al. 2015). 
Industrial processes involve using chemicals and their impact on the $\mathrm{pH}$ and ecotoxicology in water should be recognized and assessed. In Finland, legislation defines some standards on water use and quality monitoring (Finnish law (1040/2006)). In general, industrial operators in Finland are required to conduct environmental impact assessment in order to obtain permission from the designated national authorities to carry out their business (Finnish law 468/1994). Legislation (e.g. Finnish law, (1022/2006)) also sets standards and limitations on the quality of disposed water. Environmental permits and applications are accessible to the public in Finland (www.ely-keskus.fi) and, therefore, the most important contaminants in water disposal from industrial activities can be accounted for. Such data allow estimation of water protection needs, which is facilitated by appropriate legislation in Finland; however, this may not be the case in many other parts of the world.

In comparison to harvesting biomass, fossil fuel extraction, especially oil drilling, cause far more water contamination risks, such as the Deepwater Horizon disaster in 2010.

Land use and land use change Land use and land use change (LULUC) and indirect land use change (ILUC) are major issues pertaining to the tropics where natural forest lands are converted to agricultural or other uses, which may alter the environment permanently and sometimes drastically (Henders et al. 2015). Since logged forest areas in Finland are practically always regenerated, such changes do not cause any permanent land use change (LUC) impacts. Thus in the context of forestry, LUC concerns should be addressed using appropriate criteria and do not require dedicated indicators.

Operations on forest land lead to changes in land cover and soil conditions. Intensive land management such as removing vegetation (e.g. final cuttings) exposes terrains to water and wind induced erosion. Particularly erosion is a critical ecological problem in areas with steep slopes. Erosion risks are much dependent on site specific factors; however, current methods for assessing such risk are somewhat limited (Pawelzik et al. 2013). In Finland, operations such as ditching of peatland and maintenance of ditches as well as preparation of soil for reforestation can cause erosion, which could be prevented by water protection methods (Haahti et al. 2014). In general, soil erosion is not regarded as a significant problem in Finnish forests.

Soil productivity is another issue debated in forestry, especially due to the practice of intensive forest biomass use (e.g. by further harvesting logging residues), which increases nutrient removal (Thiffault et al. 2014). However, these impacts are difficult to assess and not easy to generalize due to varying site specific conditions
(Thiffault et al. 2014). In Finland, minimum standards for forest residues to be left at a site have been defined in the Finnish Forest Act (Metsälaki 1996) so that the site productivity is not significantly affected. Therefore, site or soil productivity is more of a criterion than an indicator. However, more studies are needed to assess its long-term impacts on site productivity.

Biodiversity In addition to climate impacts, biodiversity is probably one of the most important indicators to take into account in SIA. Biodiversity is a major global goal in nature conservation and has been assessed using a number of measures, such as endangered species, species richness, habitat indices, population varieties, gene pools, deadwood and habitat quality (Heink and Kowarik 2010; Filyushkina et al. 2016). However, only a few biodiversity indicators have been empirically tested against the criteria for which they were purportedly chosen (Heink and Kowarik 2010). Biodiversity is related to ES (or is the very base of the ES) and changes in biodiversity result in changes in the ES (FIBS 2015). Policy schemes often target to ensure sustainable use of resources and preserve biodiversity (Geijzendorffer and Roche 2013) and given this point of view they also aim to secure the ESs. Finnish legislation on forest management (Metsälaki 1996) specifically refers to some key habitats to be protected, and demands to oversee the regeneration of logged sites in order to preserve biodiversity.

Specific impacts of individual factors on biodiversity are not always easy to analyze. Moreover, stakeholders may have different perceptions and preferences regarding the importance of flora, fauna and abiotic factors of biodiversity, making an indicator of biodiversity difficult to assess in the decision-making process. This problem could be avoided by using the area of protection as a proxy (Cao et al. 2015a) to avoid the risk of losing biodiversity due to lack of understanding about ecosystem functions. Our current knowledge of ecosystem functions and biodiversity has large gaps and includes imperfect information. Therefore, precaution should be advocated and more studies on biodiversity are needed before operational biodiversity assessments are reliably applied in SIAs.

\section{Economic indicators}

Economic profitability is a critical measure for investments to take place. Relevance of different economic indicators may vary among private, company and national level decision-makers. The following section introduces few common indicators and a number of important aspects of economic sustainability in general and describes how they can be used for assessing the forest-based bioeconomy. The value of production by the Finnish forest industry was almost 20 billion euros 
(Metsätilastollinen vuosikirja 2014) and contributed approximately 20\% of all industrial sales in 2015 (Official Statistics of Finland 2016c). Thus, it is clear that forestry has a significant economic role in Finland.

\section{Gross domestic product}

Gross domestic product (GDP) has been suggested as an economic indicator in a number of studies (Solow 1993; den Herder et al. 2012; Hall 2015). It is an important indicator of economic activity and it also indicates well-being; however, GDP as an indicator has its own limitations (Solow, 1993). Moreover, the relationship between GDP and well-being and/or ethics has not been fully accepted; a problem as arises, for example, in the question to what extent an increase in income or wealth can generate reallife satisfaction and be equally shared (Feschet et al. 2013). In this respect, it is also important to note that economic growth based on increasing consumption of resources will eventually collide with planetary limitations (Mancini et al. 2015). Nevertheless, there is a strong relationship between GDP and national welfare, especially if the initial level of GDP has been low (Feschet et al. 2013).

GDP is a widely-applied indicator of overall economic activity and economic data is readily available from national accounts. The forest sector contributed over 4\% to Finnish GDP in 2011 (Metsätilastollinen vuosikirja 2014). However, in some counties this share is over $12 \%$ implying that the relative importance of forestry should be assessed regionally. GDP is calculated in three ways, using an output, expenditure, or income approach (see Eurostat). GDP is a global benchmark, reflecting the well-being of a nation. In addition, it is directly linked to gross national value added (GVA) as discussed below.

\section{Gross and local value added}

Gross value added (GVA) (see http://ec.europa.eu/eurostat) and local value added LVA (e.g. den Herder et al. 2012) are indicators providing information about how much the production chain adds to the value of raw materials when processed into final sales products. GVA is needed to calculate GDP and both are overlapping indicators. While GVA describes the economic contribution in broader terms (e.g. as a sector in national accounts), LVA is further restricted to describe impacts on a local (community) level. In 2013 the forest sector contributed 6 billion euros to added value (Metsätilastollinen vuosikirja 2014). Den Herder et al. (2012) defined LVA as the sum of consumer prices and subsidies deducted by the production costs and added all forest-based materials substituting fossil fuels to LVA, given that Finland has no domestic fossil fuels reserves. Virtanen et al. (2001) presented the (economic) importance of fisheries in different regions in Finland and a similar approach is possible to be applied in forestry.
The data on costs of production and products may, however, be difficult to validate. For example, to Leskinen et al. (2012), bio-refinery data were not available for reasons of trade secrets. Such a limitation in the availability of data may reflect negatively on the overall success of a SIA and prevent the application of value-added as an indicator. Furthermore, market prices, costs of production and delivery all have an impact on this indicator. Value added is especially important when considering GDP and profits. Regardless of some uncertainties involved in GVA and/or LVA, they are the essential parts of GDP and trade providing information about the distribution of economic impacts.

\section{Trade}

The annual gross value of forest industry production in Finland has been around 20 billion euros since 2010 (Forest Industries 2016). Approximately 11.5 billion euros of the value of this production is exported, contributing over $20 \%$ to all industrial exports of Finland. Hence, it is clear that the forest sector is a very important part of the Finnish economy.

In addition to wood products, forest biomass was used to generate 340 PJ of energy in 2013, while the total energy consumption in Finland (including transport fuels) was 1360 PJ (Metsätilastollinen vuosikirja 2014). These numbers show that much of the electricity and all the fossil fuels used in Finland are imported, which makes Finland very dependent on foreign energy. The energy trade has a significant economic impact: the total value of all imported energy products was 7.8 billion euros, while the value of exports amounted to 3.7 billion euros in 2015, resulting in a negative net trade balance of 4.1 billion euros (Official Statistics of Finland 2016a). Much of our wood based energy is generated from industrial side streams. Thus, in Finland increased industrial use of (domestic) wood could improve the trade balance by increasing exports and simultaneously substituting (energy) imports. The change in the import-export ratio would be a good indicator not only for policy makers to use, but also of interest to the general public when they consider supporting domestic production.

Trade forms a significant part of the national economy and trade-related statistics are well documented in Finland, making trade a ready-to-use indicator. However, market prices are not stable and may fluctuate significantly, which should be considered when applying trade indicator. In addition, trade information is related to both GDP and GVA.

\section{Social indicators}

Following Lehmann et al. (2011), the social dimension has five main categories of stakeholders: workers/employees, local communities, society (national and global), 
consumers and value chain actors. These can be further broken down into subcategories (e.g. working conditions), which can be measured by indicators (e.g. excessive hours of work). Similar categorization of indicators into impact categories can be found in Jørgensen et al. (2007)). However, some methodological and practical restrictions in integrating social indicators to decision making do exist (Lehmann et al., 2011). For example, issues of social dimension are perhaps the most casespecific ones and should be chosen accordingly. Yet site-specific data does not necessarily secure data accuracy and it is possible to modify generic data to take sites and locations into account (Jørgensen et al. 2007).

Finland has been ranked among the top nations in the world in having good social conditions (see Social Progress Imperative 2016) and a low level of corruption (Transparency International 2015). Nevertheless, there are still a number of social issues in Finland, which could be further improved (see YLE 2008). For example, income (equity and distribution) and working life issues resulting in various consequences are constantly debated in Finland. In addition, indirect social determinants such as the national economy and security may be especially interesting at the national (policy) level. Globally relevant social issues should not be neglected either, because many Finnish companies operate globally.

\section{National supply security and self-reliance}

National supply security can refer to self-reliance in matters of energy, raw-materials or food. In energy security, the traditional concept addresses availability, affordability and safety of fuels and services (Knox-Hayes et al. 2013). We have categorized this under social dimension; however, its measures have connections to environmental and economic dimensions as well.

Finland has no domestic fossil fuel reserves and thus, the Finnish energy sector relies heavily on imports: in 2015, oil, natural gas and coal constituted respectively 24,6 and $8 \%$ of total energy consumption. In addition, $20 \%$ of electricity consumed in Finland was imported in 2015 (Official Statistics of Finland 2016b) Thus, there is a clear relation in Finland between self-reliance and the use of imported energy. This reliance on imported fossil fuels exposes Finland to the risks of price and supply insecurity. In addition, importers of electricity and fossil fuels are major players in Finnish trade. Dependence on imported fossil fuels and electricity could be partially lowered with forest biomass. Thus, in the context of this study, supply security and self-reliance is seen as one of the top issues to which the forest bioeconomy may contribute in Finland. Moreover, the current combined capacity of domestic and imported electricity will unlikely be able to satisfy the peak load demand if cold winter conditions occur together with poor hydro power generation (low water levels) in the Nordic countries (Huoltovarmuuskeskus 2016) highlighting the importance of domestic energy generation.

Finnish Energy has found that that the Finns favor renewable and less environment-stressing energy sources and that they are willing to pay for these attributes (ET 2015). Knox-Hayes et al. (2013) have found that considerations for energy security globally are influenced by gender, age, demography, socioeconomic positions, level of education and many other factors. This probably suggests that understanding the "big picture" in energy production and its impacts vary globally.

Number of measures, such as changes in domestic/ imported fuels, energy and other goods, could be used when assessing this indicator on a national (policy) level. However, meaningful this measure is in the eyes of the public and needs a questionnaire-based study for evaluating broad public acceptance.

\section{Employment}

Employment has been listed as a social indicator in a number of studies and the forestry sector has strong employment impacts (den Herder et al. 2012; Leskinen et al. 2012; Tuomasjukka et al. 2013a). A common belief is that forestry-related environmental protection hampers the economy, whereas Bezdek et al. (2008) argue that this belief is untrue. Job creation includes direct, indirect and induced job creation (Dalton and Lewis 2011; Harsdorff and Philips 2013). Therefore, an accurate number of jobs being created overall may be difficult to assess (Dalton and Lewis 2011; Harsdorff and Philips 2013).

Employment has many important functions for wellbeing as employment creates income and income enables access to many functions of social well-being. In addition, increased incomes result in increased fiscal funds via taxation (the national economy).

The amount of direct jobs should be relatively simple to calculate while indirect job creation could be difficult to assess accurately. However, there are inputoutput techniques available for measuring indirect impacts of employment on the well-being of individuals and the economy at the national level (e.g. Bezdek et al. 2008). The number of employees needed is also much dependent on technologies and practices used. Therefore, case level system knowledge is essential for the precise evaluation of the employment impacts.

\section{Accidents and work-related diseases}

Many countries have paid attention to occupational accidents for over a century and the number of accidents at work has been decreasing (Hämäläinen et al. 2009). However, indirect work-related health issues such as cancer and respiratory diseases may have been underestimated 
(Hämäläinen et al. 2009). Spillemaeckers et al. (2004) proposed a quantitative health and safety indicator to be based on statistical sources and list several indicators (e.g. training, auditing and formal work policy) to measure "occupational health and safety". In Finland, good, precise statistical data are available: for example, in 2013, the official statistics about work-related accidents amounted to 134666 cases (Official Statistics of Finland 2013). The numbers show that about $6 \%$ of the work force suffered some occupational accident. The costs of accidents to a society may be significant. For example, the Finnish Institute of Occupational Health (2011) reported that the costs of work related accidents and diseases in 2000 amounted to over 4 billion euros, which is $3 \%$ of the Finnish GDP, and a one three-day absence from work costs about 5000 euros. Therefore, accidents should not be forgotten in SIAs. In other contexts, where costs of an accident fall entirely on a worker, the impact changes from society to the individual and should be addressed accordingly in SIAs.

Indicators or measures to prevent occupational accidents (e.g. Spillemaeckers et al. (2004) may be difficult to evaluate. However, some forestry related jobs may be more accident prone (e.g. transport and manufacturing) than others, although precise data may be difficult to extract from statistics (see International Labour Organization ILO 2008; Official Statistics of Finland 2013). We may use average values by sectors to estimate the number of accidents and apply those in SIAs to get approximate figures. For example, using the 6\% risk of occupational accidents it can be estimated that the 1500 new jobs created by the Äänekoski investment will result in about 90 occupational accidents annually. Nevertheless, it is obvious that more in-depth studies are needed for higher precision level calculations, especially over long time horizons on latent work-related diseases.

\section{Human health and well-being}

Health and well-being is an overall and combined result of many factors from many economic, environmental and social aspects. One method used to assess the impact of the economy on health is to study the relationship between GDP and life expectancy (LEX). Feschet et al. (2013) referred to studies mainly suggesting that although an increase in income and GDP would lead to an increase in health (in terms of LEX), after a certain level those would not further add to LEX. Thus, the level of income of an individual contrasted with the general level of income may be better in describing well-being when GDP is high (Feschet et al. 2013).

The environment is important for health and wellbeing. In general, the public understands the risks from exposure to environmental pollution (e.g. fine particles, smoking, radon, noise and UV-radiation), it does not follow that people behave accordingly (THL 2014b). As well, not all the impacts are well-known (e.g. of noise, THL 2014c). Changes in health often need time to become realized and even a 10-year period may be too short to observe all the impacts (Feschet et al. 2013). We conclude that the general health has a direct connection to work-related accidents and diseases as discussed earlier. Therefore, health and well-being at work and in life in general may be combined depending on the scope of a study. Health is also an economic issue because poor health is a financial burden to society and therefore also an economic issue. To sum up, well-being and human health is difficult to evaluate. Neither GDP nor LEX, or any other measurable indicator has been found reliable as such. Still, it is an important factor in society.

\section{Equity}

Equity between people is a critical component of social sustainability (Stanton 2012; Acevedo Tirado et al. 2015;) and one of the key matters to recognize when combatting climate change (UN 2015). The level of equity among people varies greatly around the globe. Therefore, regional contexts should be considered. Equity can be understood broadly as shared, equal rights, rules and responsibilities between all individuals in a society or, alternatively narrowly considering "only" wealth and income (see Stanton 2012). Stanton (2012) also argues that, although income distribution may be an insufficient metric of equity, it is still by far the bestmeasured component of equity for being associated, for example, with better environmental, health and education outcomes and robust overall social capital. We would also argue that corruption is a global threat to both equity and sustainability. However, in Finland, corruption is not a major issue and Transparency International has scored Finland among the least corrupt nations for many years (Transparency International 2015). As well, labor conditions can be harsh and exploitative in many countries. In this regard, if increased use of wood in Finland were to move jobs from labor discriminating countries to Finland, labor conditions should improve. Another question is how job losses would impact the people there where the jobs were taken from, given that globally operating Finnish forest companies work for equity, for example by improving labor conditions, but all employers might not do the same.

Problems related to equity in a broader sense may differ considerably between developed and developing countries. For example, in Finland, many important equity functions such as access to health care and education are either free or costs are compensated by the 
government and also accessible (and even compulsory to a certain degree) to every citizen (The Social Insurance Institution of Finland, 2016; Finnish constitution, 731/ 1999). In 2015, Finland was ranked as the 3rd most equal nation among the 145 countries accounted for by the World Economic Forum (2015). All the same, there are some inequity issues even in Finland, such as that high job positions are mostly occupied by men (Eurostat 2016) and unequal income distributions between genders and among people in general are a reality in Finland (Official Statistics of Finland 2014c). Several methods to assess income distribution among citizens have been considered, for example by Champernowne (1974), who considered the Gini-index as a suitable indicator in income inequality assessment. Calculation of the Ginicoefficient needs salary data which are still more or less a taboo in Finland. Access to taxation data would allow a comprehensive use of the Gini-coefficient, but that information is commonly available to tax officials only.

In the context of this study, salary and the equal distribution of profits and income along the whole chain of actors (e.g. the forest bioeconomy production chain from forest owners to pulp/paper mills) could work as an applicable and relevant indicator. In this way, equity (development) could be assessed and known anticipated (positive) development should result in higher overall acceptance of a decision (social sustainability), but this would be possible only if income data were made openly available, which is rarely the case. Imperfect information about salaries make income based equity development uncertain. But, labor unions in Finland do set recommendations on salary levels for different jobs which could be further used to assess the income levels following any project.

\section{Capacity and freedom}

Nussbaum (2011) discussed many basic human rights and capability issues (e.g. freedom of association, free choice of occupation and political liberty). Many of these may seem to be distant to people in countries where the ability to do or to become something is mainly related to disposable income and available time but not with gender or ethnical status as in many other locations. Aboriginal people (e.g. Sami people in northern Finland) are a special case of capacity and freedom to consider in decision-making to maintain their culture and society.

In general, employment and income dictate most issues of capacity and freedom. However, while income is only instrumentally important for freedom, some income thresholds may be set to assess freedom and capacity (Hall 2015). Thus, the impact of employment and income could be set as threshold criteria for minimum standards in salary and employment creation when applied in SIA. However, participation (see next section) may improve the feeling of capacity and freedom experienced among people.

\section{Participation}

Sustainability and general acceptability of a decision may be improved by information delivery and opportunities in participation. Strong presumptions and attitudes, such as that jobs are lost due to environmental protection (Bezdek et al. 2008), may result in supporting suboptimal decisions. To avoid these issues, information should be addressed in an understandable way and decisions should be based on verified information. Transparency and participation are both essential in decision-making to avoid public distrust towards decision makers (Drew and Nyerges 2004; Fenster 2006), fighting against corruption and in defending democratic principles.

Finland has a long tradition in participation of stakeholders in decision-making and policy-processes (Lindstad and Solberg 2012). Stakeholder participation is an important part of sustainable forest management, since planning problems in forestry often include multiple criteria and preferences set by many stakeholders and/or decision makers (Kangas et al. 2015). Public participation is possible, among others, via meetings, workshops, tours, newsletters, interactive information networks and social media.

Planning cases that include multiple stakeholders may face difficulties due to conflicting viewpoints and preferences. Kangas et al. (2015) list the aims of participation in forestry as follows:

1. "Increase awareness of forestry issues and mutual recognition of interests.

2. Gather information and enhance knowledge on forests and their use.

3. Improve provision of multiple forest goods and services.

4. Stimulate involvement in decision-making and/or implementation process.

5. Enhance acceptance of forest policies, plans and operations.

6. Increase transparency and accountability of decision-making.

7. Identify and manage conflicts and problems together, in a fair and equitable way."

Based on these listed aims of participation, we argue that an active multi-lateral participation process should be a criterion for sustainable decision making.

\section{Rural-urban development}

Migration from rural to urban areas is an ongoing development resulting from changes in societal structures 
and public preferences, which eventually drive people to pursue jobs, education and higher living standards from urban livelihoods (Rye 2006). The disappearance of rural jobs and the consequential depopulation of rural areas further diminishes the capacity of rural areas to provide the services and fulfill the needs of the remaining rural population (Stockdale 2004). However, depopulation of rural areas is not always a desired course of development and out-migration from the countryside is often considered as negative (Rye 2006). This is because many of the people moving to urban areas would prefer to live in the countryside but see this as impossible due to a lack of jobs and services (Stockdale 2004). Therefore, ruralurban development reflects, to some extent, the capacity and freedom-indicator.

Rural-to-urban migration can also be used to indicate the impacts of decisions on social conditions and health of rural areas. For example, job creation is a critical factor for rural development and if forests were to be utilized more intensively, new jobs would be created in rural areas since this raw material is mostly located in rural areas. In addition, processing facilities are often located close to the source of raw material for logistic reasons. Hence, decisions fostering the forest bioeconomy could play a role in revitalizing and maintaining inhabited rural areas. Assessing job locations is possible and we would encourage assessing rural development in SIA with rural job creation.

\section{Indicator summary}

Based on the discussion so far, we have compiled the indicators we recommend for consideration when assessing sustainability of the forest bioeconomy (Table 1). We have categorized and given examples of units and connections as well as data sources for each indicator.

The indicators provided in Table 1 are widely applicable within many contexts, including those outside the forestry sector. However, some of these (e.g. biodiversity) may be difficult to assess. We do not think that all the criteria in Table 1 must be applied in every assessment even though many may improve the value of information in the SIA significantly, especially regarding acceptance by the public.

\section{Tools for SIA}

SIA (in 3D format) can be described as a process-based approach, assessing sustainability impacts connected to processed materials, which becomes a tool for comparing alternatives (Tuomasjukka et al. 2013b). The aim of SIA is to provide quantified results of impacts from various dimensions resulting from an operation. However, as discussed earlier, it is not possible to state everything in quantitative terms. Thus, qualitative approaches may also be needed. We first need to measure and quantify the impact of each indicator and then evaluate the results. Evaluation of results of an indicator can be conducted, for example, by using indicator weights and priorities according to the information provided by the decision makers and stakeholders. Finally, weighted values can be aggregated to obtain an overall picture of the sustainability impacts of each alternative. The decision maker can then choose the best ranked alternative based on the analysis.

Many tools and methods and their combinations have been presented for assessing sustainability. In a 3D- SIA format, we need to consider that the variables we measure vary greatly between dimensions, while the complexity increases if the issue becomes a multi-stakeholder case. Moreover, regional differences across the globe (e.g. in culture, practice or site) make it impossible to generalize the assessments. For example, the "best" option may lead simultaneously to positive impacts on some and negative impacts on other aspects which the various stakeholders may evaluate differently. Typically, there is no method that could be regarded as the 'best' or 'the-one-and-only' in any assessment case. Instead, a mix of methods is often called for (Kangas et al. 2015).

Before weighting and aggregation, we first need to measure individual indicators and their impacts. In the following, we introduce several methods used in impact assessments. We emphasize that none of these is suited to fully assess all indicators. The tools/methods presented below are the most common ones found in the indicator related literature. Additionally, some detailed information about tools and methods were obtained by following the references cited in the literature or using especially tool names as keywords. Table 2 at the end of this section summarizes the tools, their orientations, strengths and weaknesses and examples of extensions and combinations with other tools.

\section{Cost-benefit analysis}

Cost-benefit analysis (CBA) estimates a benefit attained via monetary values, but can also incorporate nonmonetary values. CBA has been criticized for being limited in democratic (Söderbaum 2015) and ethical (Hall 2015) considerations. Hall (2015) has considered CBA suitable for its practical benefits, given that it is based on monetary units and the possibility for it being used together with other approaches. CBA works well in assessing monetary values, which is its strengths since economic evaluation as such is objective-oriented and suitable for policy-making cases. Criticism related to the CBA approach has emerged due to the challenges in monetizing all inputs and outputs and/or outcomes. In a forestry context, recreation, non-wood goods and scenic beauty are examples of values difficult to evaluate in economic terms. Therefore, supplementary methods 
Table 1 Indicators categorized in dimensions, examples of units, inter-linkages to other aspects and/or indicators of sustainability and possible data sources

\begin{tabular}{|c|c|c|c|c|c|}
\hline Indicator & Dimension & $\begin{array}{l}\text { Indicator unit(s) } \\
\text { (in example) }\end{array}$ & $\begin{array}{l}\text { Strong indicator } \\
\text { interlinkages }\end{array}$ & Other major connections & $\begin{array}{l}\text { Main data and/or } \\
\text { cofactor sources }\end{array}$ \\
\hline $\begin{array}{l}\text { Greenhouse gases } \\
(\mathrm{GHG})\end{array}$ & Environmental & $\mathrm{tCO}_{2 \text { eq, }} \mathrm{GWP}$ & Fossil fuel use & Biodiversity & National statistics \\
\hline Fossil fuel use & Environmental & tons, $\%$ - of all fuels & $\begin{array}{l}\text { GHG, trade, national } \\
\text { self-reliance }\end{array}$ & Renewable energy & $\begin{array}{l}\text { National statistics, } \\
\text { industry }\end{array}$ \\
\hline Fine particle emission & Environmental & $\begin{array}{l}\text { particle sizes }>10,1-10 \\
\text { and }<1 \mu \mathrm{m}\end{array}$ & Fossil fuel use & Health & $\begin{array}{l}\text { Industry, literature, } \\
\text { derivable from other } \\
\text { indicators }\end{array}$ \\
\hline Water contamination & Environmental & $m^{3}$ & & $\begin{array}{l}\text { Ecosystem services, } \\
\text { fossil fuel use }\end{array}$ & Industry \\
\hline $\begin{array}{l}\text { Land use and land } \\
\text { use change }\end{array}$ & Environmental & ha & Biodiversity & (indirect) GHG & $\begin{array}{l}\text { National statistics, } \\
\text { Industry (e.g. wood use) }\end{array}$ \\
\hline Biodiversity & Environmental & $\begin{array}{l}\text { Area protected/area used, } \\
\text { species richness, }\end{array}$ & & Harvested forest area & Experts, industry \\
\hline $\begin{array}{l}\text { Gross domestic } \\
\text { production (GDP) }\end{array}$ & Economic & $€, \%$-change in GDP & GVA/LVA & & National statistics \\
\hline $\begin{array}{l}\text { Gross and/or local value } \\
\text { added (G/LVA) }\end{array}$ & Economic & $\begin{array}{l}€ \text { added to product per } \\
\text { m3 wood used }\end{array}$ & GDP, Trade & Rural development & $\begin{array}{l}\text { Industry, (Inter)National } \\
\text { statistics }\end{array}$ \\
\hline Trade & Economic & Import/export change & $\begin{array}{l}\text { GDP, G/LVA, National } \\
\text { supply security and } \\
\text { self-reliance }\end{array}$ & National self-reliance & National statistics \\
\hline $\begin{array}{l}\text { National supply security } \\
\text { and self-reliance }\end{array}$ & Social & Import/Total energy use & Fossil fuel use, Trade & & $\begin{array}{l}\text { National statistics, } \\
\text { industry }\end{array}$ \\
\hline Employment & Social & Person years & Accidents, salaries & $\begin{array}{l}\text { Capacity and freedom, } \\
\text { well-being }\end{array}$ & $\begin{array}{l}\text { National statistics, } \\
\text { industry }\end{array}$ \\
\hline $\begin{array}{l}\text { Human health and well- } \\
\text { being }\end{array}$ & Social & N/A & $\begin{array}{l}\text { Fine particle } \\
\text { emissions }\end{array}$ & $\begin{array}{l}\text { Accidents and work related } \\
\text { diseases, social costs. }\end{array}$ & $\begin{array}{l}\text { Questionnaires, } \\
\text { industrial accounting. }\end{array}$ \\
\hline $\begin{array}{l}\text { Accidents and work } \\
\text { related diseases }\end{array}$ & Social & $\begin{array}{l}\text { Person days-off/working } \\
\text { days }\end{array}$ & Employment & & $\begin{array}{l}\text { National statistics, } \\
\text { industry, Insurance } \\
\text { institutions }\end{array}$ \\
\hline Equity & Social & Paid salaries, Gini-index & Employment & $\begin{array}{l}\text { Reflections to health and } \\
\text { Capacity and freedom }\end{array}$ & $\begin{array}{l}\text { National statistics, } \\
\text { industry }\end{array}$ \\
\hline Capacity and freedom & & $\begin{array}{l}\text { Disposable income, } \\
\text { Free time }\end{array}$ & Participation & Rural development & Questionnaires \\
\hline Participation & Social & $\begin{array}{l}\text { Number of participants, } \\
\text { Number of hearings }\end{array}$ & $\begin{array}{l}\text { Capacity and } \\
\text { freedom }\end{array}$ & Equity & Public documentation \\
\hline Rural development & Social & Rural/urban jobs & Employment & $\begin{array}{l}\text { Equity and Capacity } \\
\text { and freedom }\end{array}$ & $\begin{array}{l}\text { National statistics, } \\
\text { Industry }\end{array}$ \\
\hline
\end{tabular}

may be needed for incorporating values for intangible and non-monetary factors in CBA (Prokofieva et al. 2011). If non-monetary values are incorporated in CBA, it may also be considered a multi-criteria analysis (MCA, introduced below) tool.

\section{Input-output and environmentally extended input-output analysis}

Input-Output (IO) analysis is a tool where an input (a resource) is converted into some output (a product) and the interdependencies between the various sectors of the economy are assessed for their impacts (Leontief 1966). For example, the input of wood to a sawmill resulting in outputs from the sawmill may be a direct part of the forestry sector, although it utilizes inputs from other sectors such as energy and transportation. Naturally, other inputs (e.g. labor, water or chemicals) are also needed in these processes (Mattila et al. 2011).

To be more informative, IO has been extended to include also environmental (see Leontief 1970) and social (see Päivinen et al. 2010) aspects. Environmentally extended input-output analysis (EEIO) (Koskela et al. 2011; Leontief 1970), for example, derives its environmental impacts by using economic tables used in traditional, material and economically focused IO. A strength of EEIO analysis is that economic IO data are often well documented. In addition, the assumption of linear (market) responses between demand and production without 
Table 2 Sustainability assessment tools shown with their orientations, main strengths and weaknesses and examples of their extensions and combinations with other tools

\begin{tabular}{|c|c|c|c|c|}
\hline Tool & Orientation & Strengths & Weaknesses & Extensions \& combinations \\
\hline $\begin{array}{l}\text { Cost-benefit } \\
\text { analysis (CBA) }\end{array}$ & Economic & $\begin{array}{l}\text { Monetary valuation of gained benefits. } \\
\text { Monetized impacts are especially } \\
\text { suitable to policy making. The total } \\
\text { of benefits for society is possible to } \\
\text { make well illustrated. }\end{array}$ & $\begin{array}{l}\text { Problems in ethical and democratic } \\
\text { considerations. Value is often } \\
\text { subjective. Allocation of total costs } \\
\text { to one benefit is invalid - e.g. odor } \\
\text { reduction itself does not cost the }\end{array}$ & $\begin{array}{l}\text { Combination with other tools } \\
\text { to monetize the non-monetary } \\
\text { values and vice versa, for } \\
\text { example with input-output. }\end{array}$ \\
\hline
\end{tabular}

\begin{tabular}{|c|c|c|}
\hline $\begin{array}{l}\text { Input-output } \\
\text { (IO) methods }\end{array}$ & Economic & $\begin{array}{l}\text { Economic tables are commonly } \\
\text { available for } 10 \text {-analysis and are well } \\
\text { and reliably documented. Preciseness } \\
\text { is better if markets are well-known. } \\
\text { Especially suitable for industry once } \\
\text { cost structure and profitability is applied. }\end{array}$ \\
\hline
\end{tabular}

$\begin{array}{ll} & \begin{array}{l}\text { Environment } \\ \text { (environment } \\ \text { extended IO) }\end{array} \\ & \\ \text { Life cycle } & \text { Environment } \\ \text { analysis (LCA) } & \text { (ELCA) } \\ \text { methods } & \end{array}$

Social (SLCA)

Economic (LCC)

Material flow Environment analysis (MFA)

Multi-criteria Any analysis (MCA)
Economy is often of high interest to any decision maker and economic information supports social impact assessment too.

Environmental extension of $\mathrm{IO}$ is obtainable from commonly available statistics.

Comprehensive consideration of all inputs and emissions of a product during its life-cycle. Inclusion of indirect emissions, such as those from steel or fossil fuel production. Standardized method and comprehensive databases are available.

Social aspects are often connected to economic and ecological issues. Hence, much data is available.

Focus on loads of materials needed in production of a specific (end) product enables identification of inefficient material uses and production phases. Can be comprehensive, yet simple to operate.

Number of approaches available. Enables thorough evaluation and balancing between alternatives with respect to indicators, dimensions and stakeholders via outranking, weighting, voting, for example. Inclusion of intangible and highly subjective aspects is possible. reduction itself does not cost the full value of the investment.

Assumption of linear market responses. Markets needs to be well established and known for higher certainty levels. In this case, the new products make much uncertainty and pulp and paper experience much price fluctuations.

Shares the weaknesses of 10 . In addition, EE-IO may produce large datasets which are cumbersome to operate.

Highly demanding in data and large data sets are demanding to handle. Datasets not always available, but access only via costly licenses.

Datasets outdate fast. Datasets not

fully transparent in documentation

Methods to assess and derive social impacts from existing data are in infant state. Cannot be directly attached to environmental LCA because of high site specific nature.

Some economic information may be difficult to obtain because of trade secrets. Market price fluctuations and changes in consumption patterns cause uncertainties

May inherit a limited view in respect to inclusion of externalities outside the examined system.

Known unsustainable alternatives need to be excluded beforehand. Preferences have to be obtained e.g. via questionnaires which may make the MCA. Stakeholders' lack of knowledge and risk of personally biased preferences may corrupt the evaluation.
Extensions to environmental dimension (EE-IO).

LCA databases or MFA calculations may be applied

Combination with material flow analysis possible.

Data from other LCA methods

Combining with OI, MFA or the other LCA methods is possible.

MFA-model tools are capable to add many different indicators if the functional unit permits it. Combination with LCA is possible.

Multi-criteria analysis can use results of any impact assessment method. MCA method then has to be chosen accordingly to the task complexity and data availability. thresholds in the EEIO method eases product-impact allocation to demand categories. However, the assumption of linear markets is also a weakness of the IO analysis since linear market responses are not often the case in reality (Mattila et al. 2011). Moreover, the data may create large matrices that are computationally cumbersome. It is possible to extend EEIO analysis to a multiple-region analysis, which allows allocation of impacts between regions by using import and export data.

\section{Life-cycle assessment, Life-cycle costing and Social life cycle assessment}

Life-cycle assessment (LCA) is a widely-adopted and standardized method, which uses a functional unit as a reference to measure environmental, economic and social impacts of a product over its full life cycle (Finkbeiner et al. 2006). Depending on the case and data availability, LCA applies to a consequential or attributional approach (Pawelzik et al. 2013). 
In environmental life cycle assessment (ELCA) the results are put in environmental impact categories, (e.g. global warming, acidification and human toxicity), which can be used for exploring and evaluating the trade-offs between alternatives (Stranddorf et al. 2005). A systematic overview inherit in ELCA enables identification of environmental burdens shifting between the life-cycle stages. However, large data sets may make it difficult to apply (Finkbeiner et al. 2006). Data sets and software are available for ELCA, although often there are licenses to be paid for their access and use.

In addition to the environmental dimension, LCA can be extended to economic and social dimensions (Finkbeiner et al., 2006) by using life-cycle costing (LCC) or life cycle cost assessment (LCCA) (Homagain et al. 2016), environmental life cycle costing ELCC (Hall 2015) and social life-cycle assessment (SLCA) (Lehmann et al. 2011). Homagain et al. (2016) conducted LCCA by combining LCA data with cost information in a biochar production case. LCC adopts the economic consideration of a "cost" where money or its equivalent is sacrificed for some benefits (to the organization) to be realized immediately or in the future. A monetary consideration limits the possible aspects to be considered; however, the concept of value can be extended to any value cost for any value gain, which resembles costeffectiveness analysis or CBA (Hall, 2015).

SLCA analyzes and reports social impacts of a product over its life cycle. It can utilize, for example, emissions, working hours or hectares, obtainable in calculations to assess various social impacts. However, SLCA is not a well-established method (Jørgensen et al. 2007) and much development work is needed for SLCA to make it more comprehensive and robust (Macombe et al. 2013). Dreyer et al. (2006) conclude that SLCA is a potential tool that can promote economic and social conditions around the world. A combination of environmental and social LCA with LCC could be applied to measure the impacts from all three dimensions simultaneously. Combining the various life cycle approaches may be difficult because, for example, the environmental impact of two practices may be similar, but social impacts may still differ significantly (Jørgensen et al. 2007).

\section{Material flow analysis}

Material flow analysis (MFA) is a method focusing on the amount of material used in a production chain and assesses the impacts the process causes (Hendriks et al. 2000). In MFA, a certain unit of raw material fed into a system, is examined (e.g. an industry, household, region) that produces certain outputs from the system. MFA calculates all the inputs needed in the process and outputs that the inputs produce. MFA normally considers loadings of inputs and outputs instead of their concentrations (Hendriks et al. 2000). In the context of forestry, a MFA-model called ToSIA (Tool for Sustainability Impact Assessment) has been developed by the European Forest Institute (Wolfslehner et al. 2011). In ToSIA, material flows are calculated in tons of organic carbon and the impacts are calculated by using multipliers for each material unit used in each process resulting in an impact total (Tuomasjukka et al. 2013b). The results of MFA can be used to compare scenarios or to examine the material flow in an individual chain (e.g. den Herder et al. (2012).

\section{Multi-criteria analysis}

The overall assessment of sustainability in 3D framing with varying stakeholder preferences calls for methods to prioritize the dimensions and the indicators. This means that decision makers and stakeholders indicate their preferences to the relative importance of different dimensions and indicators of sustainability. In addition, some normative thresholds may be needed to exclude unsustainable (but possible) alternatives. By using measurable and operational criteria (Kangas et al. 2015), we can outrank alternatives that are not clearly meeting the fundamentals of sustainability.

The main approaches of weighting and aggregation include multiple attribute utility/value theory (MAUT/ MAVT), outranking methods and other non-classical approaches (De Mare et al. 2015). In forestry, Kangas et al. (2015) introduce a wide array of alternative decision support methods. According to Kangas et al. (2015), problems with multiple dimensions, including uncertainty, are among the most challenging ones and the uncertainty may reside in any of the factors (e.g. in consequences and preferences) in decision (or impact) analysis. Accordingly, Hall (2015) found that the various stakeholders did not consider same costs equally relevant. Multi-criteria decision support tools have been developed for complex, multiple criteria evaluation tasks and decision-making processes (Kangas et al. 2015).

A number of multi-criteria analysis (MCA) methods have been developed. Each method has different qualities and characteristics and is suitable for various kinds of tasks and problems. Among them, Kangas et al. (2015) consider the stochastic multi-criteria acceptability analysis (SMAA) as a tool fit for discrete cases and stochastic goal programming for continuous cases including uncertainty. The analytic hierarchy process (AHP) is another possible tool (Kangas et al. 2015). Furthermore, a combination of SMAA and Preference Ranking Organization Method for Enrichment Evaluations (PROMETHEE, an outranking method) methods has been introduced by Corrente et al. (2014) to permit holistic multi-criteria comparison of alternatives. Simply stated, these methods use different ways to rank alternatives 
according to the criteria provided by stakeholders and/ or outrank alternatives using these criteria. In this sense, MCA methods apply the impact data obtained with other tools presented earlier.

\section{Discussion}

Multidimensional sustainability has become the mainstream ideology in decision-making over previously favored resource-centered approaches (Tuomasjukka et al. 2013a). However, it is estimated that the current humaninduced disturbances have exceeded the planetary limits and more irreversible damage is constantly taking place (Ayres et al. 2001; Mancini et al. 2015). A major transition in our society is needed for the return back to the ecological boundaries of the Earth. The forest bioeconomy is likely to play an important role in this transition but easy paths for change seem to be missing. In addition, the transition process could cause much societal changes in all 3Ds along its way, some of which may be drastic, for example, on sectors depending of fossil material and in areas with large forest resources. Fossil-based activities can partly be turned into renewable-based ones, so that the transition including energy production and employment generation, could occur relatively smoothly. Moreover, there is much uncertainty involved in the environmental sustainability of using forests because their highly complex functions of ecosystems and responses to disturbances are not well-known. This lack of understanding the complexities in nature may easily result in unsustainable decisions, for example in unintended over exploitation of forests because some response to a disturbance was unknown. Especially long term responses and changes in natural functions due to disturbances call for a greater understanding so that the overall sustainability of the forest bioeconomy can be secured.

Difficulties in assessing sustainability start from the very beginning - what is sustainable and how to define sustainability? After considering some definitions of sustainability, their measurements and fair evaluation of the impacts and preferences introduce further uncertainties to assessments. In the end, unknowns are inherent in any assessment since "perfect" data is never available. Uncertainties are unavoidable and they should be taken into account prior to making any decisions. With careful planning and good system-level understanding, it is possible to minimize the risks of negative impacts due to misjudgments. One could argue that the more we pursue "perfect" knowledge before making a decision, the more we make decision-making impossible. Thus, we should act towards stronger sustainability and think that any action towards a higher level of sustainability is always better than continuing on a path already known to be unsustainable.
The core of the global sustainability trend is to substitute fossil fuels and materials with renewable alternatives. In this endeavor, we should maximize the benefits and minimize the negative impacts during and after the transition. To do this, comprehensive SIAs are needed. However, indicators and their impacts are sometimes difficult (if not impossible) to measure or estimate accurately. In addition, tolerance and acceptability of impacts vary among stakeholders as much as they are region-specific. Thus, making an overall balanced, acceptable and sustainable decision turns from a trivial into a complex task. A successful execution of a SIA calls for a set of indicators, which suit the context, tools and methods to make an overall evaluation of the impacts. Furthermore, the assessments should apply LC-approaches to avoid shifting problems from one location or a step in production to another.

One difficulty that arises when producing a 3D sustainability assessment of the forest bioeconomy is how to take into account the life cycle perspective properly in the aggregation step. In particular, LCA provides standardized and well-known tools; however, this mainly concerns the environmental dimension. The social and economic modeling through LCA is more difficult than the environmental dimension alone and the selection of a set of social indicators can also be problematic. For example, if a typical set of indicators in SLCA, including indicators such as child labor, were expanded to include the acceptability of stakeholders, the indicators could be measured even though they would not be LCA-based measurements as such. This will introduce problems with the aggregation of the social dimension with the environmental dimension since the measurements are not necessarily restricted to the same system boundaries, given that the decision alternatives compared are not the same in all dimensions of sustainability. This issue would need further research and the applicability of concepts such as life cycle thinking instead of life cycle assessment should be studied.

MCA methods complement a range of methods available for sustainability assessment. They can be used in commensuration with the dimensions of sustainability as well as with criteria and indicators within those dimensions. MCA is a well-developed, still evolving and widely applied branch of operations research. MCA methods provide flexible tools, especially for case-wise analyses when the cases vary in their characteristics and needs.

Sustainability assessment is a process, where tools, dimensions, indicators, approaches and decision support methods link together (Fig. 1). Different combinations may be used and a combination is chosen according to the objective of the case. Increased activity in the forest bioeconomy to substitute fossil raw material, for example, creates various positive and negative impacts at 


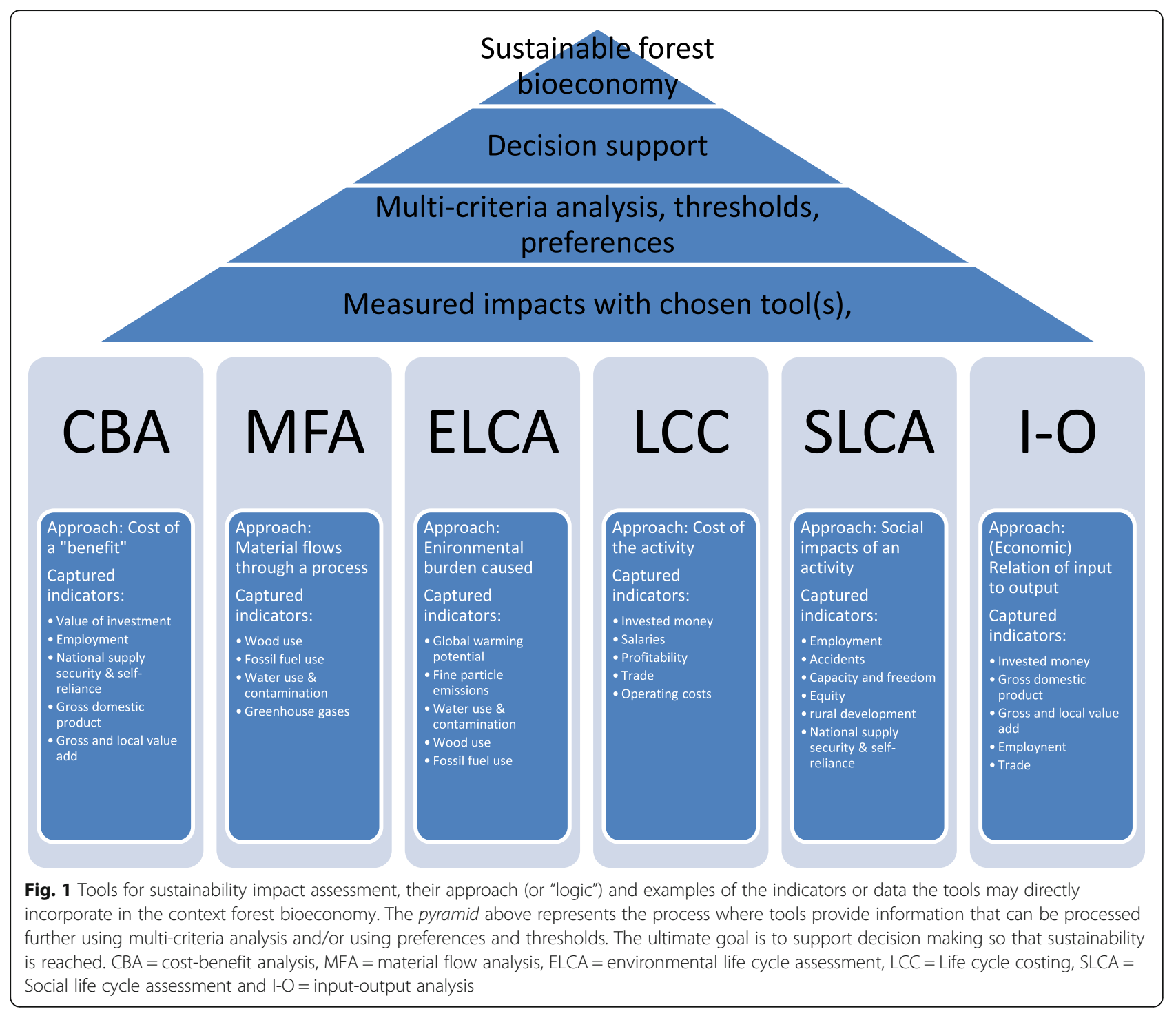

many levels as shown in Fig. 2, which categorizes the positive and negative impacts in a Finnish context according to our opinion. We hypothesized that a restricted number of indicators would be enough to cover the most important determinants of sustainability and provide a reliable SIA. This, we think, is a false hypothesis. The reason for this denial of the hypothesis is that a SIA is not about indicators, but about what these indicators include. Sustainability is the compilation of a wide range of preferences, values and many unknown factors. Hence, the fewer individual indicators we refer to, the more attributes each referenced indicator should include, making the conduct of a SIA not easier without predefined relationships between attributes. Therefore, we should encourage studying more the consequential impacts of readily available data, such as GDP or wood use.

\section{Conclusions}

The need for a quick transition due to environmental degradation and climate change does not allow us to wait endlessly for some all solving innovations to emerge in the future. Instead, there is an urgency to act now and prevent further permanent harm to our planet. Therefore, we should trust our current knowledge to assess the impacts of our practices accordingly, make the most sustainable decisions we can and redirect operations towards even more sustainable methods upon availability of increasing reliable information.

The forest-based bioeconomy will play its part in the fossil-to-renewable transition and is especially important in countries rich in forests, such as Finland. We discussed and provided a set of indicators that we considered relevant and operable for conducting a SIA. In addition, we presented several 


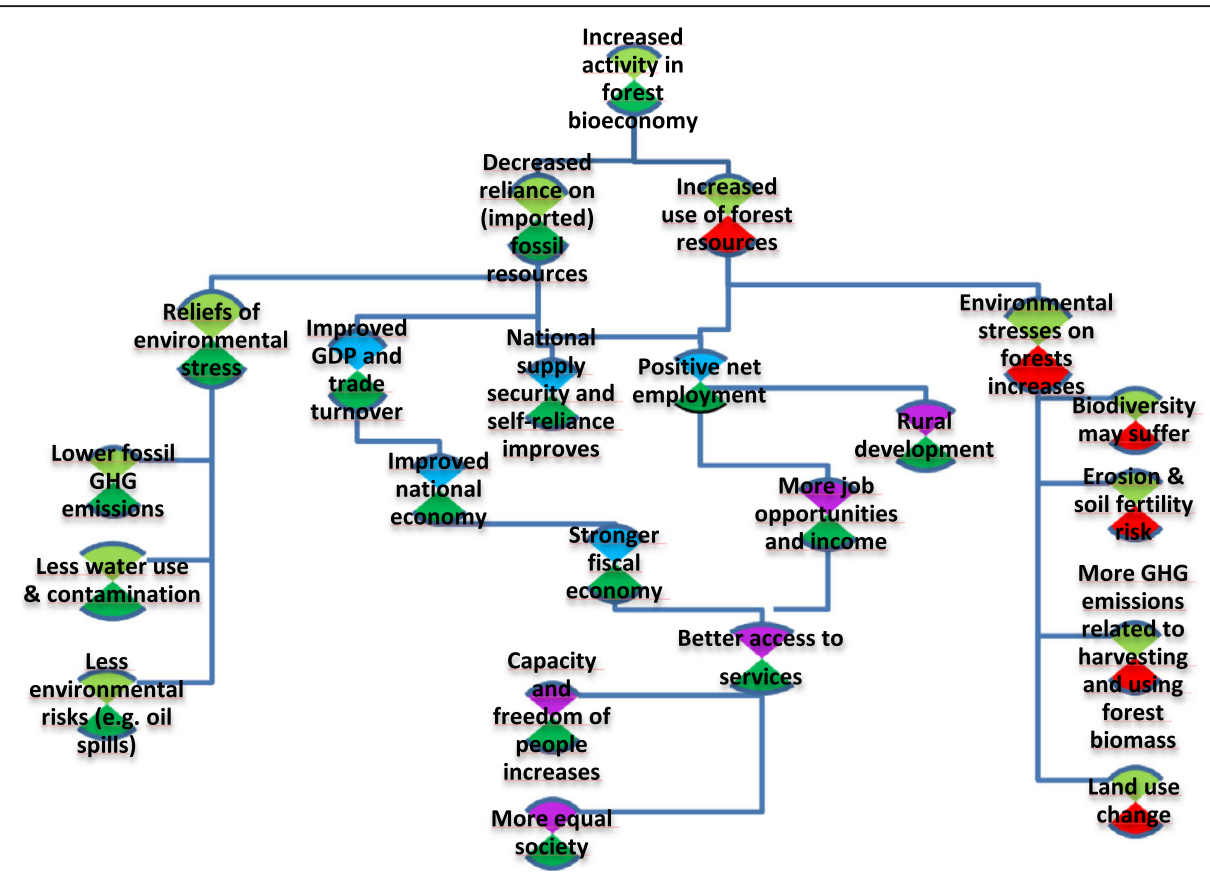

Fig. 2 A topological illustration how increased activity in forest bioeconomy cause impacts on national level. The upper colors in each represent the main dimension of the impact: green stands for environmental, blue for economic and purple for social dimension, respectively. The lower color stands for the "expected direction" of the impact in respect to sustainability: green for positive, and red for negative

commonly acknowledged tools and methods for evaluating sustainability impacts and to make sustainable and justified decisions.

The literature on sustainability presents many tools and indicators. Therefore, the main problem in assessing sustainability is not a lack of methods. Instead, data availability, practical application and imperfect understanding about how the impacts are interconnected and crossing over dimensions are the limiting factors. We recognize that it is important to continue to study concepts and methods related to sustainability to assess it properly. First, a robust and science-based knowledge of the sustainability thresholds about the planetary boundaries is needed. Second, more studies are needed to make it possible to apply more indicators in SIAs (e.g. biodiversity indicators). We also found that many of the sustainability and impact assessment related terms are more or less ambiguously defined and their meanings greatly differ. For example, some had taken the multidimensionality of LCA for granted whereas in some cases the inclusion of more than one (environmental) dimension was seen as an extension of the method. Therefore, more consistent and standardized definitions are needed.

In a continuation study, we plan to conduct a real-life assessment related to forest bioeconomy activity and apply this study as the core for our indicators and tools to assess its sustainability.

\section{Abbreviations}

3D: Ecological, economic and social dimensions; CBA: Cost-benefit analysis; EEIO: Environmentally extended input-output analysis; ELCC: Environmental life cycle costing; ES: Ecosystem services; EU: The European union; GDP: Gross domestic product; GHG: Greenhouse gas; GVA: Gross value added;

GWP: Global warming potential; IEA: International energy agency; IO: Input-output analysis; LCA: Life cycle analysis; LCC: Life cycle costing; LCSIA: Life cycle sustainability impact assessment; LVA: Local value added; MCA: Multi-criteria analysis; MFA: Material flow analysis; RE: Renewable energy; SIA: Sustainability impact assessment; SLCA: Social life cycle analysis

\section{Acknowledgements}

This study was supported by the research project "Sustainable, climate-neutral and resource-efficient forest-based bioeconomy" funded by the Strategic Research Council at the Academy of Finland (Council (Decision No. 293380). We wish to thank Leena Rännäli for her contribution to language editing.

\section{Authors' contributions}

The corresponding author wrote most of the text and conducted most of the data gathering. Each co-author provided their invaluable expert insights, opinions and recommendations for the text and wrote certain important paragraphs. In addition, the second author took the main responsibility for the language editing before the final spell check by a professional editor. All authors read and approved the final manuscript.

\section{Competing interests}

The authors declare that they have no competing interests.

\section{Author details}

${ }^{1}$ Finnish Environment Institute, Yliopistokatu 7, 80100 Joensuu, Finland. ${ }^{2}$ University of Eastern Finland, Faculty of Science and Forestry, School of Forest Sciences, P.O. Box 111, 80101 Joensuu, Finland.

Received: 31 August 2016 Accepted: 25 January 2017 Published online: 23 February 2017 


\section{References}

Acevedo TA, Ruiz MM, Lobato-Calleros O (2015) Additional Indicators to Promote Social Sustainability within Government Programs: Equity and Efficiency. Sustainability 7:9251-9267. doi:10.3390/su7079251

Akhtari S, Sowlati T, Day K (2014) The effects of variations in supply accessibility and amount on the economics of using regional forest biomass for generating district heat. Energy 67:631-640. doi:10.1016/j.energy.2014.01.092

Ayres RU, van der Bergh JCM, Gowdy JM (2001) Strong versus weak sustainability: economics, natural sciences, and "consilience.". Environ Ethics 23:155-168. doi:10.5840/enviroethics200123225

Bezdek R, Wendling R, Diperna P (2008) Environmental protection, the economy, and jobs: national and regional analyses. J Environ Manage 86:63-79. doi:10. 1016/j.jenvman.2006.11.028

Cambero C, Sowlati T (2014) Assessment and optimization of forest biomass supply chains from economic, social and environmental perspectives - a review of literature. Renew Sustain Energy Rev 36:62-73. doi:10.1016/j.rser 2014.04.041

Cao V, Margni M, Favis BD, Deschênes L (2015a) Aggregated indicator to assess land use impacts in life cycle assessment (LCA) based on the economic value of ecosystem services. J Clean Prod 94:56-66. doi:10. 1016/j.jclepro.2015.01.041

Cao T, Hyytiäinen K, Hurttala H, Valsta L, Vanclay JK (2015b) An integrated assessment approach to optimal forest bioenergy production for young scots pine stands. For Ecosystems 2:19. doi:10.1186/s40663-015-0043-6

Champernowne DG (1974) A comparison of measures of inequality of income distribution. Econ J 84(336):787-816. doi:10.2307/2230566, http://www.jstor. org/stable/2230566. Accessed 2 Jan 2017

Cieślak S, Gaj K (2014) Hazards of uncontrolled methane release from clathrates analyse and environmental evaluation of extraction methods. Environ Prot Eng 40(3):99-111. doi:10.5277/epe140308

Corrente S, Figueira JR, Greco S (2014) The SMAA-PROMETHEE method. Eur J Oper Res 239:514-522. doi:10.1016/j.ejor.2014.05.026

Czeskleba-dupont R (2012) A secular carbon debt from atmospheric high temperature combustion of stem wood? J Transdiscipl Environ Stud 11(2):37-47

Dalton G, Lewis T (2011) Metrics for measuring job creation by renewable energy technologies, using Ireland as a case study. Renew Sustain Energy Rev 15: 2123-2133. doi:10.1016/j.rser.2011.01.015

De Mare G, Granata M, Nesticò A (2015) Weak and strong compensation for the prioritization of public investments: multidimensional analysis for pools. Sustainability 7:16022-16038. doi:10.3390/su71215798

Decision No 406/2009/EC (2009) Decision No 406/2009/EC of the European Parliament and of the Council of 23 April 2009 on the effort of Member States to reduce their greenhouse gas emissions to meet the Community's greenhouse gas emission reduction commitments up to 2020. http://eur-lex. europa.eu/legal-content/EN/TXT/?qid=1462866037943\&uri=CELEX: 32009D0406. Accessed 18 May 2016

den Herder M, Kolström M, Lindner M, Suominen T, Tuomasjukka D, Pekkanen M (2012) Sustainability impact assessment on the production and use of different wood and fossil fuels employed for energy production in North Karelia, Finland. Energies 5:4870-4891. doi:10.3390/en5114870

Drew C, Nyerges T (2004) Transparency of environmental decision making: a case study of soil cleanup inside the Hanford 100 area. J Risk Res 7:33-71. doi:10.1080/1366987042000151197

Dreyer L, Hauschild M, Schierbeck J (2006) A framework for social life cycle impact assessment. Int J LCA 11(2):88-97. doi:10.1065/lca2005.08.223

Ernst WG (2012) Overview of naturally occurring Earth materials and human health concerns. J Asian Earth Sci 59:108-126. doi:10.1016/j.jseaes. 2012.05.030

ET (2015) Energiateollisuus ry (Finnish Energy) (2015) Suomalaisten Energiaasenteet. Available via ET. http://energia.fi/ajankohtaista_ja_ materiaalipankki/materiaalipankki/suomalaisten_energia-asenteet_2015. html. Accessed 15 May 16

EU directive 2015/2193 (2015) Directive (EU) 2015/2193 of the European Parliament and of the Council of 25 November 2015 on the limitation of emissions of certain pollutants into the air from medium combustion plants. http://eur-lex.europa.eu/legal-content/EN/TXT/?qid=1451477031803\&uri= CELEX:32015L2193. Accessed 18 May 2016

EU regulation No 525/2013 (2013). Regulation (EU) No 525/2013 of the European Parliament and of the Council of 21 May 2013 on a mechanism for monitoring and reporting greenhouse gas emissions and for reporting other information at national and Union level relevant to climate change and repealing Decision No 280/2004/EC. http://eur-lex.europa.eu/legal-content/ EN/TXT/?qid=1462866037943\&uri=CELEX:32013R0525. Accessed 17 May 2016

Eurostat (2016) Your key to European statistics, (data up to March 2016). http://ec.europa.eu/eurostat/statistics-explained/index.php/Gender_ statistics\#Labour_market. Accessed 17 May 2016

Fenster M (2006) The opacity of transparency. lowa Law Rev 91:885-949. doi:10.2139/ssrn.686998

Ferranti F (2014) Energy wood: A challenge for European forests Potentials, environmental implications, policy integration and related conflicts. EFI technical report 95. Available via EFI. http://www.efi.int/files/attachments/ publications/efi_tr_95_ferranti_2014.pdf. Accessed 2 Jan 2017

Feschet P, Macombe C, Garrabé M, Loeillet D, Saez AR, Benhmad F (2013) Social impact assessment in LCA using the Preston pathway: the case of banana industry in Cameroon. Int J Life Cycle Assess 18:490-503. doi:10.1007/s11367-012-0490-z

FIBS (2015) Lisäarvoa luonnosta ympäristöä säästäen - Biodiversiteetti ja ekosysteemipalvelut ympäristöstrategian lähtökohtana. Available via FIBS. http://www.fibsry.fi/fi/tilaisuudet/icalrepeat.detail/ 2016/01/27/202/-/yritykset-biodiversiteetti-vuosiseminaari-2016. Accessed 15 May 2016

Filyushkina A, Strange N, Löf M, Ezebilo EE, Boman M (2016) Non-market forest ecosystem services and decision support in Nordic countries. Scand J For Res 31:99-110. doi:10.1080/02827581.2015.1079643

Finkbeiner M, Inaba A, Tan R, Christiansen K, Klüppel HJ (2006) The New international standards for life cycle assessment: ISO 14040 and ISO 14044. Int J Life Cycle Assess 11:80-85. doi:10.1065/lca2006.02.002

Finnish Law (1022/2006) (2006) Government Decree on Substances Dangerous and Harmful to the Aquatic Environment (1022/2006). Finlex data bank, Finnish National legislation. http://www.finlex.fi/en/laki/kaannokset/2006/ en20061022. Accessed 15 May 2016

Finnish constitution 731/1999 (1999) Finlex data bank, Finnish National legislation. http://www.finlex.fi/fi/laki/ajantasa/1999/19990731. Accessed 15 May 2016

Finnish law (1040/2006) (2006) Government Decree on Water Resources Management (1040/2006). Finlex data bank, Finnish National legislation. http://www.finlex.fi/en/laki/kaannokset/2006/en20061040?search[type]= pika\&search[pika]=2006. Accessed 15 May 2016

Finnish Law (468/1994) (1994) Act on Environmental Impact Assessment Procedure (468/1994). Finlex data bank, Finnish National legislation.http:// www.finlex.fi/en/laki/kaannokset/1994/en19940468. Accessed 15 May 2016

Finnish law (750/2013) (2013) Government Decree on the environmental protection requirements of energy production units with a rated thermal input below 50 MW (750/2013). Finlex data bank, Finnish National legislation. http://www.finlex.fi/en/laki/kaannokset/2013/en20130750?search[type]= pika\&search[pika]=50\%20megawatt. Accessed 15 May 2016

Finnish law (936/2014), (2014) Government Decree on Limiting Emissions from Large Combustion Plants, (936/2014). Finlex data bank, Finnish National legislation. http:// muw.finlex.fi/en/laki/kaannokset/2014/en20140936?search[type]=pika\&search[pika]= large\%20combustion. Accessed 15 May 2016

Finnpulp (2015) Finnpulp Oy plans a major green field softwood pulp mill investment to Kuopio. Press release, Feb 2. 2016. http://www.finnpulp.fi/ press-archive/finnpulp-oy-plans-a-major-green-field-softwood-pulp-millinvestment-to-kuopio.html. Accessed 29 June 2016

Forest Industries (2016). https://forestindustries.fi/statistics/industry/10Forest\%20Industry/. Accessed 2 Jan 2017

Geijzendorffer I, Roche P (2013) Can biodiversity monitoring schemes provide indicators for ecosystem services? Ecol Indic 33:148-157. doi:10.1016/j. ecolind.2013.03.010

Haahti K, Bassam AY, Stenberg L (2014) Unsteady flow simulation and erosion assessment in a ditch network of a drained peatland forest catchment in eastern Finland. Water Resour Manag 28:5175-5197. doi:10.1007/s11269-014-0805-x

Haatanen A, den-Herder M, Leskinen P, Lindner M, Kurttila M, Salminen O (2014) Stakeholder engagement in scenario development process - bioenergy production and biodiversity conservation in eastern Finland. J Environ Manage 135:45-53. doi:10.1016/j.jenvman.2014.01.009

Hall M (2015) A transdisciplinary review of the role of economics in life cycle sustainability assessment. Int J Life Cycle Assess 20:1625-1639. doi:10.1007/s11367-015-0970-z

Hämäläinen P, Saarela KL, Takala J (2009) Global trend according to estimated number of occupational accidents and fatal work-related diseases at region and country level. J Safety Res 40:125-139. doi:10.1016/j.jsr.2008.12.010 
Harsdorff M, Philips D (2013) Methodologies for assessing green jobs. ILO, Policy brief, Feb. 2013. Available via ILO. http://www.lo.org/global/topics/green-jobs/ publications/WCMS_176462/lang-en/index.htm. Accessed 15 May 2016

Heink U, Kowarik I (2010) What criteria should be used to select biodiversity indicators? Biodivers Conserv 19:3769-3797. doi:10.1007/s10531-010-9926-6

Helin T, Holma A, Soimakallio S (2014) Is land use impact assessment in LCA applicable for forest biomass value chains? findings from comparison of use of Scandinavian wood, agro-biomass and peat for energy. Int J Life Cycle Assess 19:770-785. doi:10.1007/s11367-014-0706-5

Henders S, Persson UM, Kastner T (2015) Trading forests: land-use change and carbon emissions embodied in production and exports of forest-risk commodities. Environmental Research Letters 10(125012). doi:10.1088/1748-9326/10/12/125012.

Hendriks C, Obernosterer R, Müller D, Kytzia S, Baccini P, Brunner PH (2000) Material flow analysis: a tool to support environmental policy decision making. Case-studies on the city of Vienna and the Swiss lowlands. Local environ 5:311-328. doi:10.1080/13549830050134257

Homagain K, Shahi C, Luckai N, Sharma M (2016) Life cycle cost and economic assessment of biochar-based bioenergy production and biochard land application in Northwestern Ontario, Canada. For Ecosystems 3:21. doi:10.1186/s40663-016-0081-8

Huoltovarmuuskeskus (2016) Selvitys keinoista sähkötehon riittävyyden varmistamiseksi kulutushuipuissa, 2016. Available via National Emergency Supply Agency. huoltovarmuuskeskus.s3-eu-west-1.amazonaws.com/app/ uploads/2016/09/08165658/917.pdf. Accessed 30 Jan 2017

IEA (2015) International Energy Agency 2015. Key World Energy Statistics Available via IEA. https://www.iea.org/publications/freepublications/ publication/key-world-energy-statistics-2015.html. Accessed 16 May 2016

International Labour Organization (ILO) (2008) Department of statistics, http://laborsta.ilo.org/STP/guest. Accessed 15 May 2016

IPCC (2014) (Intergovernmental Panel on Climate Change) Climate change 2014, Impacts, Adaptation and Vulnerability. Part A: Global and Sectoral Aspects. Available via IPCC. http://www.ipcc.ch/report/ar5/wg2/. Accessed 18 Aug 2016

Janeiro L, Patel MK (2015) Choosing sustainable technologies. Implications of the underlying sustainability paradigm in the decision-making process. J Cleaner Prod 105:438-446. doi:10.1016/j.jclepro.2014.01.029

Jäppinen E, Korpinen O-J, Laitila J, Ranta T (2014) Greenhouse gas emissions of forest bioenergy supply and utilization in Finland. Renew Sustain Energy Rev 29:369-382. doi:10.1016/j.rser.2013.08.101

Jørgensen A, Le Boca A, Nazarkina L, Hauschild M (2007) Methodologies for social life cycle assessment. Int J LCA 13(2):96-103, http://dx.doi.org/10.1065/lca2007.11.367

Kaidi (2016) Chinese Kaidi plans to build a $€ 1$ billion biodiesel plant in Kemi. Press release 10 Feb 2016. http://www.kaidi.fi/uutiset-tiedotteet/2015/12/3/ tiedote. Accessed 29 June 2016

Kangas A, Kurttila M, Hujala T, Eyvindson K, Kangas J (2015) Decision Support for Forest Management. 2nd edition, Managing Forest Ecosystems 30:310 pp. ISSN 2352-3956. doi:10.1007/978-3-319-23522-6

Klooster D (2010) Standardizing sustainable development? the forest stewardship Council's plantation policy review process as neoliberal environmental governance. Geoforum 41:117-129. doi:10.1016/j.geoforum.2009.02.006

Knox-Hayes J, Brown M, Sovacool B, Wang Y (2013) Understanding attitudes toward energy security: results of a cross-national survey. Glob Environ Chang 23:609-622. doi:10.1016/j.gloenvcha.2013.02.003

Kopnina H (2016) The victims of unsustainability: a challenge to sustainable development goals. Int J Sustain Dev World Ecol 23:113-121. doi:10.1080/ 13504509.2015.1111269

Koskela S, Mäenpää I, Seppälä J, Mattila T, Korhonen MR (2011) EE-IO modeling of the environmental impacts of Finnish imports using different data sources. Ecol Econ 70:2341-2349. doi:10.1016/j.ecolecon.2011.07.012

Kouki J, Hyvärinen E, Lappalainen H, Martikainen P, Similä M (2012) Landscape context affects the success of habitat restoration: large-scale colonization patterns of saproxylic and fire-associated species in boreal forests. Divers Distrib 18(4):348-355. doi:10.1111/j.1472-4642.2011.00839.0078

Lamberg H, Nuutinen K, Tissari J, Ruusunen J, Yli-Pirilä P, Sippula O, Tapanainen M, Jalava P, Makkonen U, Teinilä K, Saarnio K, Hillamo R, Hirvonen MR, Jokiniemi J (2011) Physicochemical characterization of fine particles from small-scale wood combustion. Atmos Environ 45:7635-7643. doi:10.1016/j.atmosenv.2011.02.072

Lehmann A, Russi D, Bala A, Finkbeiner M, Fullana-i-Palmer P (2011) Integration of social aspects in decision support, based on life cycle thinking. Sustainability 3:562-577. doi:10.3390/su3040562

Leontief W (1966) Input-output economics. Oxford University Press, New York Leontief W (1970) Environmental repercussions and the economic structure: an input-output approach. Rev Econ Stat 52(3):262-271. doi:10.2307/1926294
Leskinen P, Kähkönen T, Lähtinen K, Pasanen K, Pitkänen S, Sironen S, Myllyviita T, Sikanen L, Asikainen A (2012) Moniulotteinen kestävyyden arviointikehikko puuenergian tuotannolle. Suomen Ympäristö 9. ISSN: 1796-7637

Levasseur A, Lesage P, Margni M, Brandão M, Samson R (2012) Assessing temporary carbon sequestration and storage projects through land use, land-use change and forestry: comparison of dynamic life cycle assessment with ton-year approaches. Clim Change 115:759-776. doi:10.1007/s10584-012-0473-x

Lindstad BH, Solberg B (2012) Influences of international forest policy processes on national forest policies in Finland, Norway and Sweden. Scand J For Res 27:210-220. doi:10.1080/02827581.2011.635079

MacDicken KG, Sola P, Hall JE, Sabogal C, Tadoum M, de Wasseige C (2015) Global progress toward sustainable forest management. For Ecol Manage 352:47-56. doi:10.1016/j.foreco.2015.02.005

Macombe C, Leskinen P, Feschet P, Antikainen R (2013) Social life cycle assessment of biodiesel production at three levels: a literature review and development needs. J Clean Prod 52:205-216. doi:10.1016/j.jclepro.2013.03.026

Mancini MS, Galli A, Niccolucci V, Lin D, Bastianoni S, Wackernagel M, Marchettini N (2015) Ecological footprint: refining the carbon footprint calculation. Ecol Indic 61:390-403. doi:10.1016/j.ecolind.2015.09.040

Mattila T, Leskinen P, Mäenpää I, Seppälä J (2011) An environmentally extended input-output analysis to support sustainable use of forest resources. open for sci j 4:15-23

McKechnie J, Colombo S, Chen J, Mabee W, MacLean HL (2011) Forest bioenergy or forest carbon? assessing trade-offs in greenhouse gas mitigation with wood-based fuels. Environ Sci Technol 45:789-95. doi:10.1021/es1024004

MCPEF (1993) Resolution H1. General Guidelines for the Sustainable Management of Forests in Europe. Second Ministerial Conference on the Protection of Forests in Europe 16-17 June 1993: 1-5

Metsä Group (2015) The next-generation bioproduct mill. Press release, Sept. 21. 2015. http://bioproductmill.com/articles/metsa-group-to-build-nextgeneration-bioproduct-mill-in-aanekoski. Accessed 5 Oct 2016

Metsälaki (1996) The Finnish forest act. http://www.finlex.fi/fi/laki/ajantasa/1996/ 19961093\#L1P1. Accessed 15 Apr 2016

Metsätilastollinen vuosikirja (2014). http://www.metla.fi/metinfo/tilasto/julkaisut/ vsk/2014/. Accessed 1 Dec 2016

Moriana R, Vilaplana F, Ek M (2015) Forest residues as renewable resources for bio-based polymeric materials and bioenergy: chemical composition, structure and thermal properties. Cellul 22:3409-3423. doi:10.1007/ s10570-015-0738-4

Nussbaum MC (2011) Capabilities, entitlements, rights: supplementation and critique. J Hum Dev Capabilities 12:23-37. doi:10.1080/19452829. 2011.541731

Official Statistics of Finland (2013) Occupational accident statistics. ISSN = 17979544. http://www.stat.fi/til/ttap/2013/ttap_2013_2015-11-27_tie_001_en.html. Accessed 10 May 2016

Official Statistics of Finland (2014a) Industrial output. http://www.stat.fi/til/tti/ 2014/tti_2014_2015-12-02_tie_001_en.html. Accessed 5 Oct 2016

Official Statistics of Finland (2014b) Trade 2014. http://tilastokeskus.fi/tup/suoluk/ suoluk_kotimaankauppa.html. Accessed 5 Oct 2016

Official Statistics of Finland (2014c) Tulonjaon kokonaistilasto tuloerot 2014, part 2. Suurituloisimman kymmenyksen tulotaso kuusinkertainen pienituloisimpaan kymmenykseen nähden. ISSN =1797-3279. http://www. stat.fi/til/tjkt/2014/02/tjkt_2014_02_2015-12-18_kat_002_fi.html. Accessed 5 Oct 2016

Official Statistics of Finland (2016a) Energy supply and consumption 4th quarter 2015. http://www.stat.fi/til/ehk/2015/04/ehk_2015_04_2016-03-23_tie_001_ en.html. Accessed 05 Oct 2016. ISSN = 1799-7976

Official Statistics of Finland (2016b) Energy. http://tilastokeskus.fi/tup/suoluk/ suoluk_energia_en.html. Accessed 5 Oct 2016

Official Statistics of Finland (2016c) Value of industrial output EUR 77.8 billion in 2015. http://www.stat.fi/til/tti/2015/tti_2015 2016-11-30 tie_001_en.html. Accessed 1 Dec 2016

Ohlström M, Lehtinen K, Moisio M, Jokiniemi J (2000) Fine-particle emissions of energy production in Finland. Atmos Environ 34:3701-3711. doi:10.1016/ S1352-2310(00)00076-5

Ohlström M, Tsupari E, Lehtilä A, Raunemaa T (2005) Pienhiukkaspäästöt ja niiden vähentämismahdollisuudet Suomessa. Kasvihuonekaasupäästöjen rajoittamisen vaikutukset. VTT tiedotteita - research notes 2300. ISBN 951- 
38-6721-8. http://www.google.fi/url?sa=t\&rct=j\&q=\&esrc=s\&source= web\&cd=4\&ved=0ahUKEwjL4rv4yqPRAhVDkiwKHRxpAq0QFggoMAM\&url= http\%3A\%2F\%2F188.117.57.25\%2Fsites\%2Fdefault\%2Ffiles\%2Ft23001. pdf\&usg=AFQjCNHBREKC_meit4TtmxHVCwMZ2Llgug\&sig2=YsmLBIREdilGBQCyg4uBg. Accessed 2 Jan 2017

Päivinen R, Lindner M, Rosén K, Lexer MJ (2010) A concept for assessing sustainability impacts of forestry-wood chains. Eur J For Res 131:7-19. doi:10. 1007/s10342-010-0446-4

Paris (2015) United Nations conference on climate change. http://www.cop21. gouv.fr/en/more-details-about-the-agreement/. Accessed 17 May 2016

Pawelzik P, Carus M, Hotchkiss J, Narayan R, Selke S, Wellisch M, Weiss M, Wicke B, Patel MK (2013) Critical aspects in the life cycle assessment (LCA) of biobased materials - reviewing methodologies and deriving recommendations, Resour Conserv Recycl 73:211-228. doi:10.1016/j.resconrec.2013.02.006

Prokofieva I, Lucas B, Thorsen BJ, Carlsen K (2011) Tools for Sustainability Impact Assessment Monetary values of environmental and social externalities for the purpose of cost-benefit analysis in the EFORWOOD project. EFI technical reports, 50:1-130. Available vie EFI. http://www.efi.int/files/attachments/ publications/eforwood/efi_tr_50.pdf. Accessed 2 Jan 2017

Rye JF (2006) Leaving the countryside: an analysis of rural-to-urban migration and long-term capital accumulation. Acta Sociologica 49:47-65. doi:10.1177/ 0001699306061899

Silveira MHL, Morais ARC, Da Costa Lopes AM, Olekszyszen DN, Bogel-kukasik R, Andreaus J, Ramos PL (2015) Current pretreatment technologies for the development of cellulosic ethanol and biorefineries. ChemSusChem 8:33663390. doi:10.1002/cssc.201500282

Sipilä J (2015) Hallitusohjelma - Pääministeri Juha Sipilän I hallituksen strateginen ohjelma [Eng. Programme of Prime Minister Sipilä's Government]. Hallituksen julkaisusarja 10, 2015. Available via VNK. http://valtioneuvosto.fi/sipilanhallitus/hallitusohjelma. Accessed 5 May 2016

Social progress imperative (2016) Social Progress Index 2016. http://www. socialprogressimperative.org/global-index/. Accessed 4 May 2016

Söderbaum P (2015) Varieies of ecological economics: Do we need a more open and radical version of ecological economics ? Ecol Econ 119:7-10. doi:10. 1016/j.ecolecon.2015.09.007

Solow R (1993) An almost practical step toward sustainability. Resour Policy 19: 162-172. doi:10.1016/0301-4207(93)90001-4

Spillemaeckers S, Vanhoutte G, Taverniers L, Lavrysen L, van Braeckel D, Mazijn B, Rivera JD (2004) Integrated product assessment - the development of the label 'Sustainable Development' for products ecological, social and economical aspects of integrated product policy. Belgian Science Policy, Belgium

Stanton EA (2012) The tragedy of maldistribution: climate, sustainability, and equity. Sustainability 4:394-411. doi:10.3390/su4030394

Stockdale A (2004) Rural Out-Migration: Community Consequences and Individual Migrant Experiences. Sociol Ruralis 44:1-28

Stranddorf H, Hoffmann L, Schmidt A (2005) Impact categories, normalisation and weighting in LCA. Danish ministry of the environment. Environ news 78:90

Suomen biotalousstrategia (2014) http://www.biotalous.fi/suomi-kehittaa/ biotalousstrategia/. Accessed 13 March 2016

Sverdrup H, Stjernquist I, Thelin G, Holmqvist J, Wallman P, Svensson M (2006) Application of natural, social, and economical sustainability limitations to forest management, based on Swedish experiences. J Sustain For 21:147176. doi:10.1300/J091v21n02_10

Tattari S, Puustinen M, Koskiaho J, Röman E, Riihimäki J (2015) Vesistöjen ravinnekuormituksen lähteet ja vähentämismahdollisuudet. Finnish environment institute reports 35. http://hdl.handle.net/10138/159464. Accessed 2 Jan 2016

The Finnish Institute of Occupational Health, 2011. Työterveys ja työturvallisuus tuottavuustekijänä. https://www.researchgate.net/publication/267950756_ TYOTERVEYS_JA_TYOTURVALLISUUS_TUOTTAVUUSTEKIJANA\#pf36. Accessed 24 Jan 2016

The Social Insurance Institution of Finland (2016). http://www.kela.fi/web/en. Accessed 16 June 2016

Thiffault E, Barrette J, Paré D, Titus BD, Keys K, Morris DM, Hope G (2014) Developing and validating indicators of site suitability for forest harvesting residue removal. Ecol Indic 43:1-18. doi:10.1016/j.ecolind.2014.02.005

THL (2014a) National Institute for Health and Welfare. Uutta tietoa ilmansaasteiden pitkäaikaisvaikutuksista. Presentation given on 21 May 2014. http://www. slideshare.net/THLfi/uutta-tietoa-ilmansaasteidenpitkaikaisvaikutuksistatimolanki. Accessed 14 May 2016

THL (2014b) National Institute for Health and Welfare 2014. Suomalaisten suhtautuminen ympäristöterveysriskeihin. Presentation given on 20 May 2014
http://www.slideshare.net/THLfi/suomalaisten-suhtautuminenympristterveysriskeihin. Accessed 14 May 2016

THL (2014c) National Institute for Health and Welfare, 2014. Ympäristömelun torjunta ja vaikutukset Presentation given on 20 May 2014. http://www. slideshare.net/THLfi/ympristmelun-torjunta-ja-vaikutukset?next_slideshow $=1$. Accessed 14 May 2016

THL (2016) National Institute for Health and Welfare. IImansaasteet 2016. https:// www.thl.fi/fi/web/ymparistoterveys/ilmansaasteet. Accessed 14 May 2016

Transparency International (2015) Corruption perceptions index 2015. http://www.transparency.org/cpi2015. Accessed 5 May 2016

Tuomasjukka D, Berg S, Lindner M (2013a) Managing sustainability of Fennoscandian forests and their use by Law and/or agreement: for whom and which purpose? Sustainability 6:18-49. doi:10.3390/su6010018

Tuomasjukka D, Lindner M, Edwards D (2013b) A concept for testing decision support tools in participatory processes applied to the ToSIA tool. Challenges 4:34-55. doi:10.3390/challe4010034

UN (2015) United Nations, Adoption of the Paris Agreement 2015. Available via UNFCCC. http://unfccc.int/resource/docs/2015/cop21/eng/l09r01.pdf. Accessed 13 May 2016

UNFCCC (1998) United Nations framework on Climate Change. http://unfccc.int/ national_reports/annex_i_ghg_inventories/reporting_requirements/items/ 2759.php. Accessed 17 May 2016

Villamagna AM, Angermeier PL, Bennett EM (2013) Capacity, pressure, demand, and flow: a conceptual framework for analyzing ecosystem service provision and delivery. Ecol Complex 15:114-121. doi:10.1016/j.ecocom.2013.07.004

Virtanen J, Ahvonen A, Honkanen A (2001) Regional socio-economic importance of fisheries in Finland. Fish Manag Ecol 8:393-403

Wolfslehner B, Brüchert F, Fischbach J, Rammer W, Becker G, Lindner M, Lexer MJ (2011) Exploratory multi-criteria analysis in sustainability impact assessment of forest-wood chains: the example of a regional case study in BadenWürttemberg. Eur J For Res 131:47-56. doi:10.1007/s10342-011-0499-z

World economic Forum (2015) World economic Forum Reports 2015. http:// reports.weforum.org/global-gender-gap-report-2015/. Accessed 22 Apr 2016

YLE (2008) The Finnish Broadcasting Company, news article on September 13, 2008. http://yle.fi/uutiset/jarjestot_nimeavat_tasa-arvo-ongelmia/5851626. Accessed 17 May 2016

\section{Submit your manuscript to a SpringerOpen ${ }^{\circ}$ journal and benefit from:}

- Convenient online submission

- Rigorous peer review

- Immediate publication on acceptance

- Open access: articles freely available online

- High visibility within the field

- Retaining the copyright to your article

Submit your next manuscript at $\boldsymbol{\nabla}$ springeropen.com 